\title{
BALANCING INCENTIVES: THE TENSION BETWEEN BASIC AND APPLIED RESEARCH
}

\author{
Iain Cockburn \\ Rebecca Henderson \\ Scott Stern
}

Working Paper 6882

http://www.nber.org/papers/w6882

\author{
NATIONAL BUREAU OF ECONOMIC RESEARCH \\ 1050 Massachusetts Avenue \\ Cambridge, MA 02138 \\ January 1999
}

\begin{abstract}
The cooperation and assistance of the firms that contributed the data used in this study is greatly appreciated. Jeff Furman provided outstanding research assistance. We thank Robert Gibbons, Tom Hubbard, Jonathan Levin, and seminar participants at the NBER IO Summer Institute, the NBER Productivity Lunch, the MIT Industrial Organization Lunch, the MIT Marketing Seminar, Harvard Business School, Kellogg, Tufts, and Charles River Associates for helpful comments; however the conclusions and opinions expressed in this paper are our own, and any errors or omissions remain entirely our responsibility. This research was funded by POPI, the Program for the Study of the Pharmaceutical Industry at MIT and by the MIT Center for Innovation in Product Development under NSF Cooperative Agreement Number EEC-9529140. Their support is gratefully acknowledged. The views expressed here are those of the author and do not reflect those of the National Bureau of Economic Research.

(1) 1999 by Iain Cockburn, Rebecca Henderson, and Scott Stern. All rights reserved. Short sections of text, not to exceed two paragraphs, may be quoted without explicit permission provided that full credit, including ${ }^{\circ}$ notice, is given to the source.
\end{abstract}


Balancing Incentives: The Tension Between

Basic and Applied Research

Iain Cockburn, Rebecca Henderson, and Scott Stern

NBER Working Paper No. 6882

January 1999

JEL No: D23, G31, J41, L65, O32

ABSTRACT

This paper presents empirical evidence that the intensity of research workers' incentives for the distinct tasks of basic and applied research are positively associated with each other. We relate this finding to the prediction of the theoretical literature that when effort is multi-dimensional, firms will "balance" the provision of incentives; when incentives are strong along one dimension, firms will set high-powered incentives for effort along other dimensions which compete for the worker's effort and attention (Holmstrom and Milgrom, 1991). We test for this effect in the context of pharmaceutical research using detailed data on individual research programs financed by private firms. Consistent with the complementarity hypothesis, we find strong evidence that firms who provide strong promotion-based incentives for individuals to invest in fundamental or "basic" research also provide more intense incentives for success in applied research through the capital budgeting process. The intensity of these "bonus" incentives is weaker in firms who use a more centralized research budgeting process. We interpret this latter finding as providing support for theories which emphasize substitutability between contractible and non-contractible signals of effort (Baker, Gibbons, and Murphy, 1994).

Iain Cockburn

Faculty of Commerce

University of British Columbia

Vancouver, BC V6T 1Z4 Canada

and NBER

cockburn@innovation.commerce.ucb.ca
Rebecca Henderson

MIT Sloan School

Cambridge, MA 02142

and NBER

rhenders@mit.edu

Scott Stern

MIT Sloan School

Cambridge, MA 02142

and NBER

sstern@mit.edu 


\section{INTRODUCTION}

Recent theoretical work on the provision of incentives inside firms has highlighted the phenomenon that incentives are often provided as "systems," where a system is composed of distinct, yet interdependent organizational design elements. One of the central propositions emerging from this literature that when the firm needs to encourage effort towards more than one distinct activity, individual elements of an incentive system that reward outcomes along each dimension will be complementary with each other (Holmstrom and

Milgrom, 1991, hereafter H\&M). Despite the potential importance of this idea for our understanding of the economics of the firm, empirical characterizations of multi-dimensional incentive systems are rare, although several careful exceptions exist (Anderson and Schmittlein, 1984; Slade, 1996; Ichniowski, Shaw, and Prenusshi, 1997; Hubbard, 1998). This may well be because identifying and measuring comparable incentive instruments across firms and over time requires detailed industry and firm-level data that is quite difficult to obtain and interpret.

In this paper, we hope to contribute to this literature by providing evidence for "balance" in the incentives provided to research workers in the pharmaceutical industry for doing both basic and applied research. In so doing, we specifically test H\&M's hypothesis that when effort is multidimensional, setting high-powered incentives along one dimension will raise the marginal returns to providing incentives along other dimensions of effort. The "balance" question arises in this context because, particularly in sciencebased industries such as pharmaceuticals, firms investing in technological innovation face a difficult tradeoff in allocating resources between long-term, "basic" or "fundamental" research activities and shortterm, directly commercializable work. Investments in basic research have no immediate payoff, but contribute to the firm's long run research capabilities, and to its' "absorptive capacity" (Cohen and Levinthal, 1989). Applied research, on the other hand, promises a more immediate return from developing marketable products. This problem is more subtle than it may first appear. To some extent the firm can strike a balance between basic and applied research by choosing a portfolio of projects lying at different points along the basic-applied spectrum. But although some projects and some research workers are highly specialized in these dimensions, most are not. Many research projects have both basic and applied aspects: the applied research activity of conducting clinical trials of a drug may generate basic insights into the epidemiology or physiology of the disease. At the same time (as a moment's introspection by an academic reader should confirm) most individual research workers face a tradeoff between allocating their time to solving the specific problem immediately at hand, or allocating it to other, more "basic" activities such as working on "blue sky" problems or investing in building or maintaining their professional competence. Run 
another analysis, catch up with the journals, or speculate about future directions for research? Work on a textbook, or write a grant?

Without perfect separation of research workers into basic and applied activities, the firm is therefore likely to have to provide a bundle of incentives designed to elicit effort in both dimensions. If the $\mathrm{H} \& \mathrm{M}$ proposition holds, then in providing these incentives the firm equalizes the marginal returns to workers' efforts in both applied and basic research activities. Increases in incentive intensity for one dimension will be accompanied by increases in incentive intensity in the other dimension. ${ }^{1}$ In the context of this study, rewarding pharmaceutical company scientists solely on the basis of their scientific reputations invites them to concentrate on writing papers and going to conferences at the expense of developing new drugs. Conversely, rewarding them exclusively for success in bring new drugs to market may result in their research productivity falling over time as they lose sight of the scientific frontier.

The second contribution of this paper is our characterization of the relatively subtle nature of incentive provision for research workers. As Holmstrom (1989) suggests, R\&D is uncertain, subject to team production, and cumulative. In such an environment, individual-level "output-based" wage incentives may be problematic to implement, and the question of what incentives should take their place is very much an open one (Hauser, 1996). Here we suggest that for established pharmaceutical firms, researchers' incentives are at least partially embedded in the criteria used for promotion and for research budgeting decisions. ${ }^{2}$ Using both the internal labor and capital markets to provide incentives also allows the firm to address some of the challenges inherent in providing incentives for research workers. For example, the capital budgeting process can be used to provide group-level rewards, which may be important in a context where the efforts of individual members are difficult to separate from the output of teams.

Our empirical investigation is based on an analysis of detailed data on research activity and organizational practices conducted within the labs of large research-intensive pharmaceutical companies over the period 1975-1990. A key feature of these data is that we observe annual research funding and research output at the level of individual research programs, such as "hypertensive therapies." We

${ }^{1}$ This can be usefully compared with the unidimensional incentive instruments studied by Lazear (1997), where auto glass installers were focused on one activity (installation speed) and variation was observed in the degree to which their payment plan was dependent on the achievement of speedy throughput.

2 Interestingly, our qualitative data suggest that during the period covered by our data, it was extremely unusual for individual researchers to be given stock options. 
construct measures of the intensity of incentive provision for the two activities of basic and applied research, and evaluate the relationship between them in the context of the multi-task agency model of H\&M. A key implication of H\&M is that, to the extent that different incentive instruments are being used to reward different activities of individual workers, then these incentive instruments will be complements. Under certain circumstances, complementarity implies that these incentive instruments will be positively associated with each other. We argue that these circumstances hold in these data and test for the proposed relationship by developing an econometric model of research budgeting decisions.

Our analysis of the incentives in place for doing basic research builds upon our previous work in which we have argued that research productivity is positively correlated with the practice of promoting individual researchers on the basis of their standing in the rank hierarchy of public science (Henderson and Cockburn, 1994). Firms' use of this mechanism is measured by a variable which was constructed for an independent exercise from qualitative data such as interview transcripts. This variable measures the degree to which a researcher's standing in the public scientific hierarchy is a critical factor in the promotion decision (we call this measure "PROPUB" for the pro-publication incentives provided by the firm). A policy of promoting individuals on the basis of their standing in the larger scientific community encourages researchers to publish actively in leading journals, to attend important conferences and in general to become active members of the broader research community. Encouraging researchers to publish is costly to the degree that it compromises intellectual property protection and induces substitution away from more applied activities, but it also ensures that the firm's researchers are closely connected to leading edge developments in fundamental science, an advantage that appears to be critical in an industry in which even relatively slight technical advances can be a source of significant commercial value. It also ensures that the firm's researchers will invest in fundamental research of the best possible quality, since their results will be subject to the scrutiny of peer review (Merton, 1973). ${ }^{3}$

Our measure of the incentive mechanism used to elicit effort in applied research is based on our observation that these firms also use changes in the research budget (i.e., the internal capital market) to reward research groups. Successful new drug candidates arise from a combination of effort by biologists, pharmacologists, chemists, and others working as part of a research team, where a typical team is

3 By using the promotion system to provide incentives for investing in long-term basic research projects, the firm increases their probability of capturing the benefits associated with such work. 
composed of 4-7 PhD scientists working together in an area of common therapeutic interest. ${ }^{4}$ In general, the firm cannot observe the separate contribution of each member of these research teams; consequently, the firm may choose to provide a "group-level" incentive or "bonus" to the group's overall budget (Holmstrom, 1982). This incentive may be particularly powerful if the (better-informed) team members can then allocate this bonus among themselves, either in the form of wage increases, hiring new researchers, or purchasing expensive capital equipment. In other words, the firm may address the problem of rewarding team production by providing rewards for successful applied research at the group level, giving each group discretion in how to allocate this "bonus."

Using our data on distinct research programs within the firm, we capture the intensity with which the firm uses this second incentive mechanism by estimating the sensitivity of the internal resource allocation process to "surprises" in a measure of the immediately commercializable research output, the “important” patents produced by a research group. Specifically, we model each program's budget as responding not only to technological opportunity (as would be predicted by a simple neoclassical theory of investment) but also to the recent performance of the research team, and interpret the magnitude of this "excess" sensitivity as a measure of the intensity of the incentive instrument, or the size of the group-level bonus.

Our central hypothesis is that these two incentive mechanisms — being "pro-publication" and using program budgeting to reward the production of patents - are complements. Our empirical work to test this follows the spirit of the proposal by H\&M (1991) in which they argue that complementary relationships between organizational design variables can be identified by their covariation, conditional on controlling for exogenous factors which determine the level of intensity with which they are used. As discussed more fully in Athey and Stern (1998), in general this methodology requires strong assumptions about the joint distribution of the errors associated with incentive instrument adoption (namely, if the errors in the adoption equation are correlated, one could observe correlation in observables due to covariation among random and unobserved costs of adoption rather than any structural interdependence between the incentive intensities).

We overcome this potential difficulty by exploiting our qualitative knowledge of the industry. First, our fieldwork suggests that the intensity of promotion-based incentives for basic research is both set

4 Our focus in this paper is exclusively on the "discovery" phase of pharmaceutical research. To become commercialized products, candidate lead compounds must be taken through the clinically-oriented development and regulatory approval process, a topic beyond the scope of the present paper. 
for a longer period of time (since there is a multi-year commitment on the part of the firm to a given level of "PROPUB") and at a higher level of authority (since such incentive schemes are explicitly chosen by the firm's senior management) than budget-based incentives for applied outputs. Further, during the period under study, there was a substantial (and exogenous) increase in the relevance of molecular biology and biochemistry for the process of drug discovery. This shift greatly increased the incentives of private firms to encourage effort by researchers towards more basic research, offering an independent source of variation in the data. With these two arguments in mind we structure our test for complementaries by examining the short-run choices of research managers in setting the intensity of rewards for applied research output, conditional on the longer-term level of the promotion-based incentives to do basic research.

Our results provide a number of insights into both the nature of internal capital markets and the use of bundles of complementary incentive instruments. There is substantial variation among firms in the degree to which they provide incentives for basic and applied research. Some firms actively encourage participation in "open science" while others discourage it. Similarly, while some firms provide relatively high-powered incentives for applied research output, in the sense that in some firms research programs' budgets are more sensitive to "surprises" in the production of patents, while for other firms there is a much more muted response to such signals. Using this variation, we find a quantitatively and statistically significant positive association between the use of these two instruments: the sensitivity of the research budget to better-than-expected patent output increases in the presence of higher reputation-based promotion incentives. The size of these effects are quite substantial. In a counterfactual, we consider a research group of average size and compare the predicted difference in the size of the bonus for a reasonably sized surprise to applied research output. Organizations which are pro-publication receive a boost to their bonus commensurate with being given permission to hire an additional junior researcher for the group. We interpret this finding as support for our key hypothesis - complementarity between basic and applied research incentives.

We also present extensions to our main empirical results which consider the role of decisionmaking authority in capital budgeting. There is evidence that the capital budget's sensitivity to patenting surprises is muted in organizations with more centralized authority structures. While we are cautious in our interpretation of this result, it is consistent with theoretical models which have emphasized the potential for substitutability between subjective and objective performance monitoring systems (Baker, Gibbons, and Murphy, 1994). Finally, our results speak to the intriguing possibility that capital budgeting may serve more broadly as an incentive instrument, in line with recent work which argues that the internal capital 
allocation process provides an important and useful window into the functioning of complex organizations (Stein, 1997; Bolton and Scharfstein, 1998).

Section II presents the theoretical model of incentive contracting which forms the basis of our analysis. Section III integrates this general structure with an explicit characterization of investment behavior to develop an estimable empirical model that allows us to test for the presence of covarying incentive instruments in the context of our panel dataset. After describing our dataset in some detail in Section IV, we then turn to a discussion of the measurement of expectations in Section V, and then to a discussion of our main results in Section VI. Section VII presents key extensions, and a concluding section suggests some directions and approaches for future research on both the provision of incentives within organizations and their possible implications for technological innovation.

\section{A MODEL OF “BALANCE” BETWEEN INCENTIVES FOR BASIC AND APPLIED RESEARCH}

Recent theoretical work on incentive contracting has generated a number of important propositions about the structure of contracts between principals and agents in situations where the agent is required to perform multiple tasks (Holmstrom and Milgrom, 1991, 1994; Baker, 1992). One of the most salient of these is that in such a multi-task model incentive intensities are complementary with one another, with the consequence that the optimal incentive regime is "balanced" — the degree to which high-powered incentives are offered along any one dimension will depend on whether high-powered incentives are offered along all other relevant dimensions. To see this more clearly, we briefly review the H\&M model and then adapt their general framework to our particular empirical setting. In particular, we exploit our qualitative knowledge about the ways in which incentives are set inside pharmaceutical firms to cast the complementarity prediction in terms of positive covariation between the sensitivity of the capital budgeting process to applied research outcomes and the degree to which the firm provides promotion-based incentives to engage in more basic long-term research.

We begin with a simple model of the provision of incentives for research workers in an employment relationship (i.e., the firm hires the workers and owns the output of their research). ${ }^{5}$ Consider

5 This formulation is distinct from analyzing the case where the ownership of intellectual property is itself endogenous. The implications of endogenous intellectual property rights has been a subject of recent interest (Aghion and Tirole (1994), Anton and Yao (1995), Gans and Stern (1997), Lerner and Merges (1998), Zucker, Darby and Brewer (1998) and Anand and Galetovic (1998)). 
a simple environment where the firm's profits are dependent on two distinct research outputs, applied and basic research. The researcher chooses how much effort, $\mathrm{e}_{\mathrm{i}}$, to devote to each research output, yielding (expected) benefits to the firm, $B=\theta_{A} e_{A}+\theta_{B} e_{B}$ less the wages paid to the researcher. For each dimension of effort, we assume that, in each period and for each dimension of effort, the firm observes a (contractible) signal, $\mathrm{X}_{\mathrm{i}}$ :

$$
\begin{aligned}
& \mathrm{x}_{\mathrm{A}}=f\left(\mathrm{e}_{\mathrm{A}}\right)+\eta_{\mathrm{A}} \\
& \mathrm{x}_{\mathrm{B}}=f\left(\mathrm{e}_{\mathrm{B}}\right)+\eta_{\mathrm{B}} \quad \eta \sim \mathrm{N}(0, \Sigma)
\end{aligned}
$$

The firm's problem is to induce optimal levels of effort by offering an incentive system which rewards workers according to the vector of observed signals, $\mathbf{X}$. By placing sufficient structure on the agent's preference function, most notably on the agent's cost function for supplying effort, it is relatively straightforward to solve for the optimal incentives. We assume that the (risk-averse) agent trades off expected income against the cost of effort:

$$
\mathrm{U}(\mathrm{w})=-\mathrm{e}^{-\mathrm{r}(\mathrm{w}(\mathrm{x}(\mathrm{e}))}-\mathrm{c}(\mathrm{e})
$$

Following H\&M, we assume that effort is costly $\left(c_{i}>0\right)$ and that the marginal cost of effort along either dimension is increasing in the level of effort along the other $\left(c_{i j}>0 \forall i \neq j\right)$. By specifying this supermodular cost function for effort on the part of the agent along with separate signals for each dimension of effort which provides benefits to the principal, our model closely mirrors H\&M, and allowing us to exploit their finding that the optimal incentive scheme takes the form of a linear reward structure relating the agent's wage to each of the observable signals:

$$
\mathrm{w}=\alpha_{0}^{*}+\alpha_{\mathrm{A}}^{*} \mathrm{x}_{\mathrm{A}}+\alpha_{\mathrm{B}}^{*} \mathrm{x}_{\mathrm{B}}
$$

where $\alpha_{\mathrm{A}}{ }^{*}$ and $\alpha_{\mathrm{B}}{ }^{*}$ are the optimally chosen incentive intensities for applied and basic research, respectively. By being able to restrict the optimal incentive scheme to the class of linear incentive schemes, $\mathrm{H} \& \mathrm{M}$ are able to further derive that the incentives for basic and applied research are complementary with one another. More specifically, we can rewrite the firm's objective function:

$$
\underset{\alpha}{\operatorname{Max}} \pi=\theta_{\mathrm{A}}\left(\mathrm{e}_{\mathrm{A}}+\eta_{\mathrm{A}}\right)+\theta_{\mathrm{B}}\left(\mathrm{e}_{\mathrm{B}}+\eta_{\mathrm{B}}\right)-\alpha_{0}-\alpha_{\mathrm{A}}\left(\mathrm{e}_{\mathrm{A}}+\eta_{\mathrm{B}}\right)-\alpha_{\mathrm{B}}\left(\mathrm{e}_{\mathrm{B}}+\eta_{\mathrm{B}}\right)
$$


Taking the cross-partial of $\alpha_{\mathrm{A}}$ and $\alpha_{\mathrm{B}}$ yields

$$
\frac{\partial^{2} \pi}{\partial \alpha_{A} \partial \alpha_{B}}=\left(\theta_{A}-\alpha_{A}\right) \frac{\partial^{2} e_{A}^{*}}{\partial \alpha_{A} \partial \alpha_{B}}+\left(\theta_{B}-\alpha_{B}\right) \frac{\partial^{2} e_{B}^{*}}{\partial \alpha_{A} \partial \alpha_{B}}-\frac{\partial e_{A}^{*}}{\partial \alpha_{B}}-\frac{\partial e_{B}^{*}}{\partial \alpha_{A}}>0
$$

where the sign of (5) follows from the fact that the effort supply function is supermodular in $\alpha_{\mathrm{A}}$ and $\alpha_{\mathrm{B}}$ : marginal effort induced by an increase in one of the intensities is increasing in the level of the other incentive intensity. An exogenous shock which encourages the firm to raise the intensity of incentives along one dimension will induce it to optimally raise the incentive intensity for the other dimension as well. Further, as suggested by H\&M and discussed more fully in Athey and Stern (1998), a key empirical implication of these indirect effects is that, under certain conditions, $\alpha_{\mathrm{A}}$ and $\alpha_{\mathrm{B}}$ will be correlated with each other in a cross-sectional dataset. Notice that this conclusion depends only on supermodularity of the effort supply function along with underlying linearity in the observables, and that consequently, this finding could have been generated from any model which includes substitutability among tasks and a lack of interaction terms between signals in the researcher's wage function.

We now tailor this prediction to the specific case of the provision of incentives for research workers in the pharmaceutical industry. We extend the framework in two specific ways. First, rather than focusing on current wage rates for individual workers, we argue that in this context the intensity of incentives, $\boldsymbol{\alpha}$, is embedded in the promotion and capital budgeting systems of the firm. Second, we argue that the long-term choice of $\alpha_{\mathrm{B}}$ is fixed from the viewpoint of the research manager's annual decision over how much to weight applied research outputs in the capital budgeting system $\left(\alpha_{\mathrm{A}}\right)$. Combining these two ideas yields a testable empirical prediction which accounts for some of the principal difficulties associated with the simple covariation test proposed by H\&M.

Consider first the question of how incentives are reflected in the organization of research in the pharmaceutical industry. While most formal models of incentives focus upon wage payments as incentive instruments, the literature also points out a number of alternatives which we believe are relevant in the context of pharmaceutical research, specifically internal labor and capital markets.

First, internal labor markets (in particular, the promotion policy of the firm) may be used effectively over the long run to induce effort on the part of workers (Doeringer and Piore, 1971; Lazear and Rosen, 1981; Gibbons and Waldman, 1998). A key insight of this literature is that when promotion confers a substantial "prize," workers will exert effort in competition against one another to generate favorable signals. In the current context, the rank hierarchy of public science may be utilized by the firm to 
differentiate among researchers; when such incentives are in place, researchers will tend to undertake effort to increase their rank.

Second, internal capital markets can be used to ameliorate agency problems within the firm (Hart, 1995; Aghion and Tirole, 1997; Stein, 1997). We believe that pharmaceutical firms routinely use the internal capital market to provide incentives for researchers, particularly for applied output. As noted above, successful new drugs are typically the result of the joint effort of a research team composed of 4-7 $\mathrm{PhD}$ scientists. Since in general the firm cannot observe the separate contribution of each member of these teams, it may optimally choose to provide a "group-level" incentive, or a "bonus" to the group's overall budget). Team members can then allocate this bonus among themselves, either in the form of wage increases, hiring new researchers, or purchasing expensive capital equipment. In other words, the firm can ameliorate the problem of rewarding team production by providing rewards for successful applied research at the group level, giving each research group discretion in how to allocate this bonus (Holmstrom, 1982).

To accommodate these alternative sources of compensation we rewrite (3) in terms of rewards provided through the internal labor and capital markets:

$$
w=\varphi^{0}+\varphi^{L A B} P\left(x_{A}, x_{B}\right)+\varphi^{C A P} B\left(x_{A,} x_{B}\right)
$$

where $\varphi^{L A B}$ is a parameter which monetizes $\mathrm{P}\left(\mathrm{x}_{\mathrm{A}}, \mathrm{x}_{\mathrm{B}}\right)$, the promotion benefit to the individual associated with observed effort, and $\varphi^{C A P}$ gives the effective benefit to the individual from the group bonus $\mathrm{B}\left(\mathrm{x}_{\mathrm{A}}, \mathrm{x}_{\mathrm{B}}\right)$. We assume a very simple structure for the promotion and bonus incentives:

$$
\begin{aligned}
& P\left(x_{A}, x_{B}\right)=\alpha_{A}^{L A B} x_{A}+\alpha_{B}^{L A B} x_{B} \\
& B\left(x_{A}, x_{B}\right)=\alpha_{A}^{C A P} x_{A}+\alpha_{B}^{C A P} x_{B}
\end{aligned}
$$

As such, this is just a slightly richer characterization of (3) and so the results regarding pairwise complementarity between each of the incentive instruments still hold. However, in order to use this result to predict patterns of empirical covariation, we must address the principal criticism associated with such arguments: the difficulty of distinguishing the presence of structural interdependence from "spurious" covariation in the unobserved costs and/or benefits from pursuing high levels of each element of $\alpha$ (Arora, 1995; Athey and Stern,1998). We do so by exploiting our qualitative understanding of how incentives are set in the context of these firms, arguing that $\alpha_{\mathrm{B}}$ is fixed in the short run. More specifically, our research 
suggests that the decision as to how to reward researchers in response to their contribution to "basic" or "fundamental" science is an important policy decision for the firm that plays a critical role in the firm's ability to hire certain kinds of human capital and that cannot be credibly changed in short periods of time. Indeed, there are only a small number of regime shifts during the entire data sample that we examine. ${ }^{6}$

From the viewpoint of the decision-maker setting the year-to-year capital budget bonuses, the only decision under her short-term control is the reward for observable measures of applied commercial output. Thus we can treat the intensity of promotion-based incentives as being at least weakly exogenous, giving us a relatively straightforward empirical test for complementarity of incentive instruments: the level of the incentives provided for applied research $\left(\alpha_{\mathrm{A}}^{\mathrm{CAP}}\right)$ should be increasing in the level of promotion-based incentives provided for basic research $\left(\alpha_{\mathrm{B}}^{\mathrm{LAB}}\right)$. In other words, the core of our empirical argument is to test whether $\mathrm{E}\left(\alpha_{\mathrm{A}}^{\mathrm{CAP}}\right) \boldsymbol{A} \alpha_{\mathrm{B}}^{\mathrm{LAB}}$, the empirical model for which we turn to in the next section.

\section{AN ECONOMETRIC MODEL OF DRUG DISCOVERY INVESTMENT BEHAVIOR}

This section develops an empirical model which yields a test of complementarity among incentive instruments aimed at basic and applied research. The model is estimated for a panel dataset constructed from annual observations on drug discovery activities in distinct research programs within the firm. This dataset is composed of over 2500 firm-program-year observations, covering 10 firms and more than 20 therapeutic areas over the period 1975 to 1990. Details of these data are provided below in Section IV.

As discussed in the previous section, our main prediction is that $\alpha_{\mathrm{A}}^{\mathrm{CAP}}$ is positively related to the level of $\alpha_{\mathrm{B}}^{\mathrm{LAB}}$, or that changes in program level research budgets should be more sensitive to "surprises" in patenting for firms with higher powered incentives for basic research. But while we observe $\alpha_{\mathrm{B}}^{\mathrm{LAB}}$

6 Our interviews suggest a number of possible explanations for this very slow rate of change. One possibility is that some researchers have strong preferences for work that is more fundamental and for an environment that encourages participation in the broader research community (Merton, 1973). An incentive system that bases at least part of the researcher's compensation on their contribution to fundamental science is likely to be particularly attractive to these kinds of researchers (Stern, 1998), and changing this element of the incentive scheme too quickly may adversely affect the reputation of the firm in the external labor markets and hence the firm's ability to recruit new researchers. As a practical matter it may be difficult to measure a researcher's contribution to fundamental science without several years of evaluation. 
directly in data compiled from interviews, $\alpha_{\mathrm{A}}^{\mathrm{CAP}}$ must be estimated indirectly from more primitive data on the firm's capital budgeting decisions. This means that we must both develop a methodology for estimating $\alpha_{\mathrm{A}}^{\mathrm{CAP}}$, and extend the logic of the "covariation" test suggested by H\&M to pose the related statistical question of whether the expected level of $\alpha_{A}^{C A P}$ is increasing in the observed level of $\alpha_{B}^{\mathrm{LAB}}$. We therefore begin our construction of this empirical test by specifying a simple model of research investment.

\section{A. A Model of Incentive and Opportunity-Driven Research Investment}

We start with an overall model of program-level research investment in which investment is driven by both technological opportunity and by the provision of incentives. A key element of this model is that investment is driven by an unbiased signal of the "excess" productivity of a research group. To compute this "surprise" we first calculate the expected level of output for each group (we consider several different implicit models of expectation formation) and then calculate the difference between observed levels of output and these expectations to obtain an estimate of the productivity "shock" perceived by the decisionmaker. This "shock" drives the subsequent budget allocation decision.

Consider a simple model of efficient investment in which the firm (costlessly) adjusts its investments each period according to "news" about underlying technological and market opportunities (Pakes, 1981; Abel, 1984),

$$
\mathrm{I}_{\mathrm{t}}^{*}=\mathrm{I}_{\mathrm{t}-1}^{*}+\gamma^{\mathrm{T}} \mathrm{T}_{\mathrm{t}-1}+\gamma^{\mathrm{W}} \mathrm{W}_{\mathrm{t}-1}
$$

where $T_{t-1}$ is the realization of a "technology shock" within a program, $\mathrm{W}_{\mathrm{t}-1}$ is unanticipated changes in opportunity generated outside the firm and $\mathrm{I}_{\mathrm{t}-1}{ }_{1}$ is the optimal investment from the prior period. While not critical for our analysis, we assume that ${ }^{\mathrm{T}}$ and ${ }^{\mathrm{W}}$ are positive; while there may be diminishing returns for any given project, scientific findings offer increasing returns on average and so in general we believe that positive "news" optimally induces greater investment in the research program. Subtracting $I_{t-1}^{*}$ from both sides yields an expression for the efficient change in investment:

$$
\Delta \mathrm{I}_{\mathrm{t}}^{*}=\gamma^{\mathrm{T}} \mathrm{T}_{\mathrm{t}-1}+\gamma^{\mathrm{W}} \mathrm{W}_{\mathrm{t}-1}
$$

We can compare (8) with (6), the specification for a program-level bonus to reward observed research effort:

$$
\tilde{\mathrm{I}}_{\mathrm{t}}=\alpha_{\mathrm{A}}^{\mathrm{CAP}} \mathrm{X}_{\mathrm{t}-1}^{\mathrm{A}}+\alpha_{\mathrm{B}}^{\mathrm{CAP}} \mathrm{X}_{\mathrm{t}-1}^{\mathrm{B}}
$$


Note that in this particular context, the firm's best measure of changes in technological opportunity is, to a great extent, also its best objective estimate of group effort $\left(T_{t-1}=\gamma_{A}^{T} x_{t-1}^{A}+\gamma_{B}^{T} x_{t-1}^{B}\right)$. Thus observed research output serves both as a measure of unanticipated changes in technological opportunity and as a measure of otherwise unobservable effort. Combining these equations yields a model of changes in the level of investment,

$$
\Delta \mathrm{I}_{\mathrm{t}}^{*}=\left(\gamma_{\mathrm{A}}^{\mathrm{T}}+\alpha_{\mathrm{A}}^{\mathrm{CAP}}\right) \mathrm{x}_{\mathrm{t}-1}^{\mathrm{A}}+\left(\gamma_{\mathrm{B}}^{\mathrm{T}}+\alpha_{\mathrm{B}}^{\mathrm{CAP}}\right) \mathrm{x}_{\mathrm{t}-1}^{\mathrm{B}}+\gamma^{\mathrm{W}} \mathrm{W}_{\mathrm{t}-1}
$$

which forms the basis of our empirical model. Estimating a structural version of (10) would require a consistent estimate of the "shock" to both the firm's expectation of applied and basic research output ( ${ }^{\mathrm{A}}$ and $x^{B}$ ). Unfortunately, we do not observe an informative measure of $x^{B}$ in this context. ${ }^{7}$ Instead, we focus on estimating a model which incorporates measures of $\mathrm{x}^{\mathrm{A}}$ based on observed data and assumes that $\mathrm{x}^{\mathrm{A}}$ and $\mathrm{x}^{\mathrm{B}}$ are uncorrelated with each other (recall that these measures are the "shocks" in the expectations and not in the levels of such variables).

\section{B. Measuring “Shocks" to Research Output}

In this setting we have a consistent and useful measure of applied research output, namely patent grants. Pharmaceutical firms file patent applications on discoveries which show commercial promise promptly, and we believe that at least in this context they are a good measure of successful outcomes in applied research projects. ${ }^{8}$ Using time series on each research group's patenting $\left(\right.$ PATENTS $\left._{\mathrm{i}, \mathrm{j}, \mathrm{t}-1}\right)$ we construct a measure of the "shock" to applied research output defined at the difference between the research group's observed and expected patenting rate,

7 By their nature, basic research outputs are difficult to observe, for the econometrician in particular. One possibility is to use "bibliometric" measures based on research publications; however, matching individual research publications is infeasible in this context since we cannot match specific individuals with specific research programs.

8 We recognize that patents may be filed on discoveries which are quite far from commercial application: in this context, putting a candidate compound into clinical trials. There is also the possibility that strategic considerations may lead firms to delay filing applications, or to pursue large numbers of otherwise insignificant applications in an effort to construct a protective "thicket" around a core discovery. However, prior work with these data, and interviews with firm personnel lead us to believe that these problems are unlikely to be a serious source of systematic bias. Note also that as discussed below, we count only "important" patents filed in two out of three major jurisdictions worldwide, and we date applications by their worldwide priority date. 


\section{$\operatorname{PATENT~SHOCK}_{\mathrm{i}, \mathrm{j}, \mathrm{t}-1}=$ PATENTS $_{\mathrm{i}, \mathrm{j}, \mathrm{t}-1}-\mu_{\mathrm{i}, \mathrm{j}, \mathrm{t}-1}^{\mathrm{PATS}}$}

where $\mu^{\text {PATS }}$ is an estimate of expected patent output from the program, $i$ indexes the research group, $j$ indexes firm, and $t$ indexes years. An immediate issue arises in that to make PATENT SHOCK comparable across programs, we need to take account of systematic technological differences across programs in the number of patents generated by a given amount of research spending. These can be very large: a million dollars spent on screening for antibiotics may generate as much as five times as many patentable candidate compounds as the same amount of resources put into cancer research. Consequently, in our empirical work, we focus largely (though not exclusively) on a version of PATENT SHOCK expressed in percentage terms

$\operatorname{PATENT~SHOCK~} \%_{\mathrm{i}, \mathrm{j}, \mathrm{t}-1}=\frac{\text { PATENTS }_{\mathrm{i}, \mathrm{j}, \mathrm{t}-1}-\mu_{\mathrm{i}, \mathrm{j}, \mathrm{t}-1}^{\text {PATS }}}{\mu_{\mathrm{i}, \mathrm{j}, \mathrm{t}-1}^{\text {PATS }}}$

Both of these measures of PATENT SHOCK require a consistent estimate of $\mu^{\text {PATS }}$, the expected level of patenting for a given firm-program-year. Obviously, the econometrician cannot construct an exact version of this expectation; each firm has access to richer information about its own programs than outside observers. However, it is feasible to model an unbiased estimate of the firm's expectation of patenting output by making assumptions about what the firm pays attention to in this process. We propose four separate models which attempt to "span the space" of reasonable models, and we compare their utility in our estimation results.

In the first, most naive, of these models, we assume that the firm's expectation is simply the level of patenting in the immediate prior year (i.e., annual patent counts follow a first-order Markov process):

$$
\mu_{\mathrm{i}, \mathrm{j}, \mathrm{t}}^{\text {MAROV }}=\text { PATENTS }_{\mathrm{i}, \mathrm{j}, \mathrm{t}-1}
$$

While this measure has obvious shortcomings, it serves as a useful baseline since it defines the most basic model of the expectations process. Indeed, $\mu^{\text {MARKOV }}$ cannot reflect either the underlying "noise" associated with the research process nor the actual level of resources devoted by the firm to the program. Our richer models begin to address these issues. In our second measure, we model the firm's expectations about each research group's performance by assuming that patent counts follow a Poisson process whose rate parameter, $\mu^{\text {POISSON }}$ can be estimated from past realizations of patent output. Specifically, $\mu^{\text {POISSON }}$ is just the mean number of patents per period over all observed periods to date, 


$$
\mu_{i, j, t}^{P}=\frac{1}{t-T_{0}} \sum_{s=T_{0}}^{t-1} \text { PATENTS }_{i, j, s}
$$

Note that a nice feature of $\mu^{\text {POISSON }}$ is that the PATENT SHOCK \% version using this estimate is precisely equal to the change in $\mu^{\text {POISSON }}$ itself:

$$
\frac{\operatorname{PATS}_{i, j, t}-\mu_{i, j, t-1}^{P}}{\mu_{i, j, t-1}^{P}}=\mu_{i, j, t}^{P}-\mu_{i, j, t-1}^{P}
$$

In other words, this measure of the "surprise" in patenting is just the difference between the current and lagged level of expected patent output.

While incorporating the historical trend in patenting in the research program, $\mu^{\text {POISSON }}$ has no adjustment for the level of funding provided to each research program or other organizational factors which may impact the firm's underlying expectation of applied research output. To overcome this limitation, we use a two-stage procedure which allows us to incorporate some of this information. (The data we have available to us is only a small subset of the information available to the decision-maker in reality, but a marked increase over just using past realizations of the patenting process.) Specifically we propose an estimate of expected patents which we term $\mu^{\mathrm{ADAPTIVE}}$ which is based on a regression-based weighting of the $\mu^{\text {POISSON }}$ measure and RESEARCH, the level of funds provided to the research program in the previous period. In the first stage, we run a Poisson regression of observed patenting on the level of research by each research group and $\mu^{\text {POISSON }}$ (which amounts to a distributed lag on patents). $\mu^{\text {ADAPTIVE }}$ is simply the fitted value of the level of patenting resulting from this Poisson regression, $\mu_{t}^{\mathrm{A}}=\hat{\lambda}_{0}+\hat{\lambda}_{\mathrm{P}} \mu_{\mathrm{t}}^{\mathrm{P}}+\hat{\lambda}_{\mathrm{R}} \mathrm{R}_{\mathrm{t}}$.

Of course, it would be possible to extend the logic of $\mu^{\mathrm{ADAPTIVE}}$ to take the fitted value from any regression-based model of the drivers of patenting productivity, $\mu_{t}^{*}=\hat{\lambda}_{0}{ }^{\prime} Z_{t}$. Indeed, in Section VII, we examine precisely such an extension by incorporating variables which capture the scale and scope of the firm's overall research organization into this regression. However, we are reluctant to impose an overly sophisticated model (e.g., a vector autoregression model which minimizes ex-post forecasting error) for essentially two reasons. In the first place, it is simply counterfactual. Research managers can and do use sophisticated quantitative tools (Nichols, 1994), but a considerable body of research has demonstrated that practicing managers rely extensively on heuristics and rules of thumb. In the second place, an overly 
specified model is actually unhelpful in this context: a fully saturated statistical model will result in "shocks" which contain less and less "signal" about unanticipated performance and more and more true random noise! Consequently, $\mu^{\mathrm{ADAPTIVE}}$ is our "preferred" measure of expectations, since we believe that it incorporates a realistic amount of information. While we doubt that research managers would update expectations without taking into account the amount of research that had been invested in a program, we are skeptical that they account (in a consistent way) for factors such as the size or structure of the firm's overall research activities.

\section{The Econometric Model}

Building on the investment model (10) and our proposed measures of the "shock" to applied research output, we propose a concrete empirical test of complementarity. As noted earlier, we cannot directly disentangle the size of the incentive being provided for applied research, $\alpha_{\mathrm{A}}$, from the response to technology opportunity, ${ }_{A}$. Instead, consistent estimation of (10) yields $\beta=\gamma_{A}^{T}+\alpha_{A}^{C A P}$, the total responsiveness to patenting in the research budgeting decision. Our test for complementarities depends, however, not on the level of $\alpha_{\mathrm{A}}^{\mathrm{CAP}}$ but on whether it is increasing in $\alpha_{\mathrm{B}}^{\mathrm{LAB}}$; moreover, as discussed more fully in the next section, we observe a direct measure of $\alpha_{B}^{\mathrm{LAB}}$. Accordingly, we model $\alpha_{A}^{\mathrm{CAP}}=\rho_{0}+\rho_{1} \alpha_{\mathrm{B}}^{\mathrm{LAB}}$. Under the assumption that our measure of $\alpha_{\mathrm{B}}^{\mathrm{LAB}}$ is independent of $\gamma_{\mathrm{A}}^{\mathrm{T}}$, we can rewrite $\beta=\gamma_{\mathrm{A}}^{\mathrm{T}}+\rho_{0}+\rho_{1} \alpha_{\mathrm{B}}^{\mathrm{LAB}}=\beta_{0}+\rho_{1} \alpha_{\mathrm{B}}^{\mathrm{LAB}}$. Substituting this back into (10) yields the following empirical specification:

$$
\Delta \mathrm{I}_{\mathrm{t}}^{*}=\left(\beta_{0}+\rho_{1} \alpha_{\mathrm{B}}^{\mathrm{LAB}}\right) \mathrm{x}_{\mathrm{A}}+\gamma^{\mathrm{W}} \mathrm{W}_{\mathrm{t}-1}
$$

Our key test is whether $\rho_{1}>0$ (i.e., $\frac{\partial \beta}{\partial \alpha_{B}^{\mathrm{LAB}}}>0 \Rightarrow \frac{\partial \alpha_{\mathrm{A}}^{\mathrm{CAP}}}{\partial \alpha_{\mathrm{B}}^{\mathrm{LAB}}}>0$ ). To complete our

empirical specification, we must introduce a source of error into (16), "normalize" the specification so that a given level of $\mathrm{x}_{\mathrm{A}}$ has a similar percentage impact across programs of different size, and introduce additional controls into . First, we divide $\mathrm{W}_{\mathrm{t}-1}$ into an observed component, $\mathrm{w}_{\mathrm{t}-1}$, and an unobserved component, $\mathrm{t}_{-1}$, which is unobserved to the econometrician. The assumption that is independent of $\mathrm{x}_{\mathrm{A}}$ 
and $\alpha_{\mathrm{B}}^{\mathrm{LAB}}$ yields a source of econometric error for (16). Second, under the measures of $\mathrm{x}_{\mathrm{A}}$ developed in the prior section, (16) implies that a given value of PATENT SHOCK yields an identical (expected) change in $I$, regardless of the level of $I$. In other words, a 1 patent "shock" would have the same budgetary impact in a $\$ 10$ million program as in a $\$ 100,000$ program. To rectify this situation, we rewrite the predictions of (16) in essentially percentage terms by scaling $\mathrm{x}_{\mathrm{A}}$ by the level of $\mathrm{I}_{\mathrm{t}-1.1}$. Finally, we include several additional regressors in to account for other factors (such as time or other firm characteristics) which may impact the level of sensitivity to our measures of shock to applied research outputs. Taken together, these amendments yield a final empirical specification for program $i$ in firm $j$ at time $t$ of:

$$
\begin{aligned}
\Delta \mathrm{I}_{\mathrm{i}, \mathrm{j}, \mathrm{t}}^{*}=\left(\beta^{\prime} \mathrm{Z}_{\mathrm{i}, \mathrm{j}, \mathrm{t}}+\right. & \left.\rho_{1} \alpha_{\mathrm{B}, \mathrm{j}, \mathrm{t}}^{\mathrm{LAB}}\right)\left(\operatorname{PATS}_{\mathrm{i}, \mathrm{j}, \mathrm{t}-1}-\mu_{\mathrm{i}, \mathrm{j}, \mathrm{t}-1}\right) \mathrm{I}_{\mathrm{i}, \mathrm{j}, \mathrm{t}-1} \\
& +\gamma^{\mathrm{W}} \mathrm{w}_{\mathrm{i}, \mathrm{j}, \mathrm{t}}+\omega_{\mathrm{i}, \mathrm{j}, \mathrm{t}}
\end{aligned}
$$

Under our assumptions, OLS estimation of (17) yields a consistent estimate of $\rho_{1}$, providing a test for complementarity between incentive intensities devoted to different tasks.

\section{THE DATA}

We estimate (17) using detailed internal data on investment and output of individual research programs, along with various measures of internal organization and incentives, for a sample of ten research-oriented pharmaceutical companies who, taken together, spend about $25 \%$ of the total amount of privately funded pharmaceutical research conducted worldwide. ${ }^{9}$ This section briefly reviews the sources of this data, the construction of the sample, and summary statistics (see Henderson and Cockburn (1996) and Cockburn and Henderson (1994) for more detail). Table 1 summarizes variable names and definitions.

\section{A. Data Sources}

FUNDING VARIABLES. Our data on research investment are taken from a database on research expenditures for several hundred individual research programs conducted by the firm in the sample between 1975-1990. These data were assembled from confidential internal records, and great care was taken to

9 The data are provided under guarantees of strict confidentiality and anonymity so we can discuss the makeup of the sample only in broad terms. The sample is relatively representative of the industry as whole, in terms of size, technical or commercial performance, and geographic distribution (with firms headquartered in both the United States and Europe). 
treat data consistently across firms and over time. The data can be divided into pre-clinical (i.e., discovery) and clinical (i.e., development) investments; here we focus exclusively on the former. ${ }^{10}$ RESEARCH is thus the level of expenditures on pre-clinical discovery research in a given firm-program-year, deflated to 1986 dollars by the NIH biomedical research deflator. We measure the "bonus" to the research budget, RESEARCH, as the first difference of RESEARCH. Similarly, FIRM RESEARCH is just the sum of RESEARCH over all observed programs of a firm in a given year.

PATENTING VARIABLES. Our measure of the objective signal of research output is based on the number of patents produced by a given firm-program-year. Patents correspond quite closely to the output of the "discovery" phase of pharmaceutical research, in the sense that they are generated by the identification of candidate compounds and represent the end of the pre-clinical phase of the research process. Of course, patents are a notoriously noisy measure of inventive activity and effort: there is enormous variation across patents in their technological and economic significance; patents are the result of a stochastic process; and there may be only a weak link between the realized level of patenting in a given year and the level of effort provided by a research group. However, despite these qualifications, we believe that patenting rates are a useful and utilized "objective" performance measure. To ensure comparability across firms, we restrict ourselves to a measure of "important" patent counts -- inventions which have been filed in at least two of three major jurisdictions (out of U.S., Europe, and Japan) -- which we believe partially controls for variation across firms in their propensity to patent "marginal" discoveries or in their national environment (patenting based on single country grants will be biased towards domestic firms). ${ }^{11}$ Moreover, we assume that the timing of the firm's patent filings is a good measure of the time at which

10 By focusing exclusively on the discovery phase of pharmaceutical research, we avoid the complexities of modeling the multi-year multi-stage development phase whereby individual drugs are moved through clinical development and testing for regulatory approval. Also note that external research grants and licensing or joint-venture payments are sometimes included in the data (as appropriate); however, these types of funding arrangement represent a very small share of the total during the period of our sample.

11 Derwent's World Patent Index compiles comprehensive data on international patent filings, allowing us to identify those granted in multiple jurisdictions. Application costs rise roughly proportionately with the number of jurisdictions, and firms rarely file in all possible jurisdictions, let alone all major markets (e.g. all OECD countries.) By excluding inventions where the firm does not file in at least two out of three major jurisdictions (US, Europe, and Japan) we are therefore left with a count of "Important Patents." Derwent's database goes back to 1962, though much less comprehensive data is available before 1970 . 
decision-makers acquire objective information about a research group's recent production of potentially commercializable compounds. Finally, we match these patents to underlying research expenditures using a classification scheme based on standard therapeutic class codes (such as the IMS Worldwide Therapeutic Classification Scheme) modified to reflect the organizational structure of the firms in the sample. ${ }^{12}$

ORGANIZATIONAL DESIGN VARIABLES. We also measure several elements of the organizational design associated with each firm-year. For the primary results of the paper, we measure the extent to which firms reward effort devoted to the pursuit of excellence in fundamental science (labeled PROPUB for "pro-publication". This is a Likert scale variable coded (1-5) which measures the degree to which the firm promotes individuals based on their standing in the external scientific community. ${ }^{13}$ Higher values of PROPUB are associated with greater commitment to performing basic research and participating in the world of "open" science. In our extension of the main results, we consider additional organizational organization design measures, which characterize the distribution of authority within the firm. The first, DICTATOR, measures the degree to which resource allocation decisions are centralized under a single individual (typically the firm's Vice President of Research) as opposed to being made by a broadly-based committee or other more diffused decision process. ${ }^{14}$ The latter measure, VICE PRESIDENT TENURE, simply tracks how long the current Vice President of Research has held their position.

TECHNOLOGICAL OPPORTUNITY INDICES. We construct several measures of the technological opportunity present in the environment by controlling for patenting both in related therapeutic areas and by other firms in the industry. In particular, we calculate three "shocks" to opportunity, exploiting the same "POISSON" methodology described in Section III, along the following dimensions:

a. the number of patents granted to competitor firms in the focus category

12 Where we were not confident about this matching, research programs and patents are assigned to a "Misc/NEC" class and not used in the analysis.

13 PROPUB is constructed from extensive interviews with senior managers and scientists, intended to capture the extent to which a firm is "pro-publication". Firms were scored according to the extent to which they encourage their scientists to participate in conferences and publish in the open scientific literature, use publication in peer-reviewed journals as an explicit criteria for promotion or other rewards, or otherwise link their internal research effort to the wider scientific community. Through appropriate selection of interview candidates and cross-checking of responses we were able to construct these scores for each firm back to 1975.

14 DICTATOR is calculated using the interview process described in FN 13. 


\section{(COMPETITORS’ PATENT SHOCK)}

b. the number of patents granted to a focus firm in therapeutic areas similar to the focus class (OWN PATENTS IN RELATED PROGRAMS SHOCK)

c. the number of patents granted to competitors in therapeutic areas similar to the focus class (COMPETITORS' PATENTS IN RELATED PROGRAMS)

The control measures for competitors' patents are drawn from a broader cross-section of firms (29 leading worldwide pharmaceutical firms) than just our 10-firm sample used in the empirical analysis.

SAMPLE SELECTION. With a complete, balanced dataset (all firms participating in all programs in all years from 1975-1990), the dataset would consist of 7040 firm-program-year observations. The dataset is unbalanced, however, affecting the size of the sample. First, and most importantly, firms initiate and discontinue research programs throughout the sample. We only include observations for which a research program is "active" in the sense that the firm actively engaged in at least some research in a particular therapeutic area (resulting in the loss of 2319 potential observations). As well, some firms are involved in mergers and some firms' discovery spending is not observed continuously between 1975-1990 (resulting in a net loss of 978 observations). Finally, 1164 observations are removed because both RESEARCH and PATENTSHOCK*RESEARCH $\mathrm{t}_{\mathrm{t}-1}$ are equal to 0 . After restricting the sample to a set of "core" research programs where we are most confident about the quality of the data, the remaining, final dataset consists of 2579 observations (though some specifications involving lagged RESEARCH consist of a restricted dataset with 1791 observations).

\section{B. Descriptive Statistics}

Table 2 presents the summary statistics for this final dataset. Beginning with the FUNDING variables, the average annual budget for an active research program is $\$ 1.57$ million, with the average firm spending \$37.52 million on drug discovery research annually (note all financial measures are in 1986 dollars, using the BEA Biomedical Research Price Deflator). Annual changes in program funding differ widely across programs, although this variable appears to be normally distributed around zero (See Figure $1)$.

In return for this investment in research, the programs in this sample yield an average of 3.2 patents per year and firms are each granted 87.7 new patents per year. Although some programs produce more than 15 patents per year, no patents are produced in 30 percent of program-years, and, for $76 \%$ of the annual observations, fewer than five patents are produced (See Figure 2). 
While the organizational variables are centered around the mean of the 5-point Likert scale, there exists substantial variation along these dimensions both across firms and across time. Both variables have minima and maxima at the extremes of the scale.

\section{MEASURING EXPECTED PATENT PRODUCTION}

A key element of our empirical work is the measurement of the sensitivity of the program-level research budget to patenting "surprises." An immediate issue arises in terms of how to measure this surprise for each firm-program-year. As discussed in Section III, our approach is to employ several measures, ranging from the extremely naive to the rather sophisticated, spanning a potentially broad space of potential models. Since these estimates are somewhat subtle (and interesting in their own right), we present a brief empirical analysis of these measures prior to turning to our main empirical results.

In Table 3, we define and present summary statistics for each of the three expectation processes. The first two (MARKOV and POISSON) are simply a calculation based on the prior patenting history of the individual firm-program-year. The MARKOV measure is simply based on the firm-program-year patent output in the immediately preceding prior year, while POISSON is simply the historical average for a given firm-program-year based on patenting records from 1966 onwards. For both measures, the calculation is based only on years for which the program is "alive" (i.e., the MARKOV measure is missing for those firm-program-year which are not at least minimally active in the immediately prior year, and the POISSON measure requires that the firm-program is minimally active in at least one year in the past). The expectation for these two measures are similar though not identical (the average MARKOV expectation is 2.42 , the average POISSON expectation is a lower value of 1.89).

An obvious flaw in these two measures is that they do not take into account the level of resources being devoted to a particular program, a problem we confront in our third measure of expectations (ADAPTIVE). This measure is the fitted value resulting from a Poisson regression of PATENTS on the POISSON measure above along with the level of RESEARCH for a given firm-program-year. As can be seen in column (iii), this regressor is highly significant and precisely estimated; the associated mean expectation is 2.60 (in Section VII, we extend this logic to consider even richer regression-based models of the firm's expectations, but, as discussed earlier, we caution against overemphasizing such rich parameterizations due to the potential for large differences across firms in how they evaluate the importance of different factors).

In Figure 3, we compare the distribution of each of our three core measures. Nor surprisingly, the distribution of the expectations is more conservative than the empirical distribution of observed patenting 
(the empirical distribution has a fatter tail to the right). However, notice that the most conservative distribution is the measure based on a simple historical average (POISSON) with a fatter tail attributed to the more richly parameterized ADAPTIVE measure.

For each of these expectation measures, we then calculate the patenting "surprise" for each firmprogram-year. We employ two functional forms for the surprise function: the level of the surprise (PATS $-\mu)$ or the percentage of the surprise $((\operatorname{PATS}-\mu) / \mu)$. The difference between these two measures is that the former implies that a one patent "surprise" holds the same information value regardless of whether the expectation is 2 or 25 patents. Accordingly, we prefer the percentage formulation, but we examine both functional forms in our empirical work, in line with our desire to demonstrate robustness to different assumptions. In Table 4, we present the summary statistics for each measures. Fortunately, the average surprise for the first two measures (MARKOV and POISSON) is small relative to their standard deviations. Moreover, by construction, the average surprise for the ADAPTIVE LEVEL measure is exactly equal to 0 (see Figure 4 for the full (nearly normal) distribution of this shock using this measure).

\section{EMPIRICAL RESULTS}

We now turn to our empirical results. Our analysis proceeds in three distinct steps. We first characterize the main result in a simple non-parametric fashion and compare how sensitive firms are to shocks to observed patent output under different organizational forms. We then build on this result more systematically and present the principal regression analysis. We first examine a base specification (in terms of the control variables included) and compare the estimates from regressions using different measures of the patent shock. The next section extends these results in several directions, which serves the additional function of demonstrating the robustness of our main qualitative results.

Recall the main prediction: changes in the program-level budget should be more sensitive to "surprises" in observed patenting for firms with more high-powered incentives for basic research. We examine this implication in a simple but direct way in Table 5. We first divide the sample into those observations for which the observed patenting levels are lower or higher than the expected value according to the Adaptive \% measure (observations with a "negative" or "positive" shock, respectively). For each of these subsamples, we divide up the data into those observations which correspond to firms with a "HI" or "LO" level of PROPUB (depending on whether PROPUB > 3 or not). Then, for each of these four mutually exclusive subsamples, we calculate the average change in the research budget from the prior year. By comparing the difference between observations which experience a negative or positive shock, we estimate a crude measure of how unanticipated research success drives a boost in research funding. In low 
PROPUB firms, a positive patent shock results in an average research budget increase of $\$ 190,000$ compared to observations associated with a negative shock; in contrast, for high-PROPUB firms, the average boost is $\$ 350,000$. In other words, the bonus for commercially oriented outputs is dramatically higher $(84 \%)$ in those organizations with the higher PROPUB levels.

We examine this finding more systematically in Tables 6 through 8. Following (17), the main specification is a regression of the change in the research budget on interactions between the patent shock and the size the program and the key organizational variable PROPUB. A number of control variables including several measures of news in technological opportunity are also included in the regressions. All three tables compare regressions with these same control variables; the differences between the regressions arise in the use of different functional forms for the patent shock, which proxies for $\mathrm{x}_{\mathrm{A}}$. Table 6 presents our preferred measures which measure $\mathrm{x}_{\mathrm{A}}$ as $\mathrm{X}^{\mathrm{A}}=\mathrm{PATENT}$ SHOCK $(\%) * \mathrm{RESEARCH}_{\mathrm{t}-1}$. Table 7 presents the corresponding estimates using the "levels" version of PATENT SHOCK. Finally, in Table 8, we explore differences in the functional form for the dependent variable along with simplifying $\mathrm{x}_{\mathrm{A}}$ to be simply PATENT SHOCK \%.

The principal results center around the interaction term between $\mathrm{X}^{\mathrm{A}}$ and PROPUB. As can be seen in Table 6, the coefficient is positive and significant for the two measures which rely on relatively sophisticated expectations measures (POISSON and ADAPTIVE). In contrast, the estimate using MARKOV is insignificant, suggesting that the stark and noisy MARKOV measure captures expected patent less precisely than the POISSON and ADAPTIVE measures. Assuming that the more sophisticated measures are more closely aligned with the process actually used within the firms, Table 6 provides evidence which is consistent with H\&M's proposition that incentive instruments directed at distinct activities are complementary.

Beyond this core result, the estimates also suggest a positive trend in research program growth over time. For each model, changes in prior period research program funding constitute the largest and most statistically significant factor predicting changes in current period funding. Other control variables enter the model less importantly. Conditional on the growth trend, the absolute size of the research program is associated with reductions in funding (although this is only significant in the POISSON-based model). Further, each of the specifications include several controls for technological opportunity (based on a "shock" measure analogous to the POISSON measure at the appropriate level of aggregation). While suggestive, these control variables are neither statistically significant nor quantitatively important. Finally, we should emphasize that while the results associated with $\mathrm{X}^{\mathrm{A}} \cdot$ PROPUB are statistically significant, the overall model has only a very weak fit (R-squared $\sim .03)$. 
Before turning to robustness and extension of these results, it is useful to provide a sense of the magnitudes involved. Consider a research program of average size (RESEARCH $=1.57)$ who experiences a positive "shock" equal to one standard deviation of the adaptive shock percentage measure (1.29). We can compare the expected change in research from this shock for an organization at the lowest level $(\mathrm{PROPUB}=1)$ versus the highest (PROPUB $=5)$. Using the estimate of 0.0155 from $(6-3)$, we calculate that the predicted difference in the bonus is equal to $\$ 125,568$, or nearly $10 \%$ of the underlying research budget and larger than the average change in the research program budget over the sample. To put this figure into some perspective, $\$ 120,000$ is greater than the cost a group faces to hire one additional junior $\mathrm{PhD}$ researcher.

Table 7 presents estimates of the model using the levels (rather than percentage) expectation measures. The results for the POISSON and ADAPTIVE models are similar to those in Table 6, with a positive and statistically significant coefficient on the interaction term with PROPUB. Once again, the MARKOV measure is insignificant (though negative), reinforcing the idea that our result depends on an assumption that the firm accounts for more than just immediately prior output when calculating its expectation of the program's patent output.

Finally, in Table 8, we use the ADAPTIVE \% measure to explore the robustness of the model to alternative specifications of the dependent variable and shock interaction term. Equation 8-1 changes the dependent variable from RESEARCH to RESEARCH. The key result on PROPUB persists in this formulation. Most notably, however, the R-squared rises to .88: most of today's research budget is explained by yesterday's research budget. This suggests that the low R-squared found for the change in research models arises from the noise in the data rather than a more fundamental misspecification of the model. Models 8-2 and 8-3 estimate equations in which the $\mathrm{X}^{\mathrm{A}}$ does not include a control for the prior level of RESEARCH in the program. As in the base specifications, equation 8-2 uses the change in research as the dependent variable; its interaction terms thus captures the sensitivity of capital budgeting without respect to program size. While the results are qualitatively similar and of similar magnitude, the coefficient on $\mathrm{X}^{\mathrm{A}} \cdot$ PROPUB is only marginally significant in (8-2).

On the other hand, (8-3) transforms the dependent variable to be in terms of the percentage change in the program's research budget (observations which are officially alive but for whose dedicated funding level is equal to zero to be discarded). In this specification, there is a statistically significant interaction between the measure of the percentage shock to expected patenting and the level of PROPUB, suggesting our main qualitative results is not driven by the specific functional form for the "shock." 


\section{EXTENSIONS: THE ROLE OF AUTHORITY AND SUBJECTIVE MONITORING}

We now extend the result we established in Section VI in three important ways. First, we examine the role of additional elements of the organizational environment, namely centralized authority over budgeting, in determining the sensitivity of program budgets to applied research outputs. Building on these additional results, we then explore the robustness of our results to the use of a richer model of the expectations process which incorporates the scale and scope of the firm's research portfolio. Finally, we examine the robustness of findings to the inclusion of various types of fixed effects.

We begin by expanding the set of organizational factors that we examine. In particular, we look at how the sensitivity of the research budgeting process to patents changes with the degree to which the research budgeting process is centralized. By examining how firms with different authority structures react differently to observable signals of applied output, we attempt to provide some insight into the role played by authority over capital budgeting within the firm. One useful way of conceptualizing the role of authority is that more centralized decisions are based on very different information sets than those used by more decentralized decision-making processes. For example, while a single manager is free to use all information available to her in the decision process, more committee-oriented decisions may be more focused on the use of objective quantifiable information - committees may be less sensitive to "opinion" than any single manager (Milgrom and Roberts, 1990). Indeed, we suggest that the use of subjective information is increasing in the degree to which resource allocation is controlled by a senior manager (a measure we label "DICTATOR"). For environments where authority is vested in a single top manager, there is a lower marginal cost of rewarding individuals based on subjective, non-contractible signals such as the quality of research presentations (as opposed to more objective measures such as patenting productivity). With this in mind, we can then draw on the work of Baker, Gibbons, and Murphy (1994) who propose that, in the case of a continuing employment relationship, objective and subjective measures of effort should be substitutes. Building on the logic developed in the earlier section, this implies that the coefficient on an interaction term between the degree of centralization and the PATENT SHOCK term should be negative, in contrast to the positive coefficient which served as a test of complementarity earlier.

We provide a preliminary test of this hypothesis by including authority measures in our estimation. Table 9 presents results for equations where DICTATOR and VP TENURE have been added.

DICTATOR is a five point Likert scale measure of the extent to which program funding is determined by a single individual, as opposed to a committee, where higher values of DICTATOR represent more centralized control of budgeting. VP TENURE represents the number of years of experience that the vice president of research has with the company. DICTATOR enters the equations significantly and with the 
expected negative sign; although VP TENURE has the expected sign, it is not significant. Further, the main result on PROPUB is robust to, and is in fact strengthened by, the addition of the authority measures. We interpret Table 9 as strengthening our confidence in our main result (concerning PROPUB) and as providing preliminary evidence consistent with Baker, Gibbons, and Murphy (1994).

The second direction in which we extend our framework is to increase the sophistication with which expected patents is estimated. In Table 10, we evaluate a fourth measure of expected patent output, which we call "SCALE \& SCOPE". Like the ADAPTIVE measure, SCALE \& SCOPE is computed as the fitted value from a Poisson regression of patenting on the POISSON measure. However, SCALE \& SCOPE is an expanded version of the ADAPTIVE measure, by adding additional regressors to capture both the scale of the firm's research activities (FIRM RESEARCH), the scope of these activities (SCOPE), and a control for the overall time trend in expected patenting output (YEAR) in its Poisson regression. (For a discussion of the relationship of these measures to productivity, see Henderson and Cockburn (1996)). Estimates using this measure are presented in Table 10. For both the levels and percentage version of the SCALE \& SCOPE measure, the principal findings are retained, buttressing our main claims. We note though, that as discussed above, using more elaborate models of expected patent output does not necessarily imply a more accurate relationship between the econometric estimate of the firm's expectation and the firm's actual beliefs. There are numerous factors that are not captured in our analysis that the firm might value, for example, changes in the specific individuals involved in the research. However, above and beyond the group's historical productivity and a summary measure of the resource commitment to the group, we believe that it will be difficult to characterize a process driving managers' expectations of research group output which is stable over time and comparable across different firms.

The final empirical direction that we pursue is that of changing the types of controls used in the principal empirical specification. Table 11 presents several models with fewer or greater controls relative to the models offered in Tables 6 through 8, using the ADAPTIVE \% measure of the "shock" variable in all specifications. In the first column, we examine a "lean" model which excludes all controls, focusing exclusively on the effects of PROPUB and DICTATOR on the sensitivity to PATENTSHOCK. Both the significance and magnitude of the key coefficients increase in absolute value, suggesting that our prior results are not being driven by the included control variables. In the latter three columns of Table 11, we increase the degree to which we control for year, firm and class effects. In (11-2), we simply include fixed "level" effects for each of these three areas with no apparent effect on the qualitative results. Similarly, when we include direct interaction terms between $\mathrm{X}^{\mathrm{A}}$ and year dummies, the results become stronger rather than weaker. However, our PROPUB result vanishes when we include a full set of firm dummies 
interacted with $\mathrm{X}^{\mathrm{A}}$; indicating that our results rely at least in part on the cross-sectional dimension of the dataset.

\section{CONCLUDING THOUGHTS}

One of the most interesting conclusions of our analysis (at least to us) is the degree to which the incentive system employed by the firm can be tailored to the idiosyncratic nature of the jobs to be performed and the available monitoring technologies. Here, in contrast to the unidimensional, commissionbased incentive schemes analyzed in most of the previous literature on this topic, we find pharmaceutical firms using a multi-dimensional incentive system to balance effort supply from researchers across the distinct tasks of basic and applied research. Rather than relying on high-powered cash incentives driven by financial performance, or "piece-rate" tallying of output, this system is built around the long-term internal labor market and the annual competition for resources in the internal capital market. We find a strong, and fairly robust statistical relationship between intensity with which the different elements of this system are used by different firms. The intensity of incentives to do applied research (the sensitivity of research funding to patent "shocks") increases with the intensity of incentives provided by the organization to do basic research (promotion based on publication in "open" refereed journals and standing in the rank hierarchy of public science). In contrast, the intensity of incentives to do applied research is lower in organizations in which decision-making authority is vested in a strong central hierarchy which has the incentive and the capability to gather and utilize subjective data on commercialization effort put forth by project teams. These results are robust to a large variety of controls (though the result becomes noisy when we rely exclusively on the time-series dimension of the data). Accordingly, we interpret our results as providing evidence that recent theories which emphasize the importance of balanced incentives and the use of multiple monitoring technologies are both empirically relevant and testable. 


\section{BIBLIOGRAPHY}

Abel, A. (1984). "R\&D and the Market Value of the Firm: A Note," $R \& D$, Patents, and Productivity, ed. Zvi Griliches. Chicago: University of Chicago Press. 261-270.

Aghion, P. and J. Tirole (1994). “The Management of Innovation," Quarterly Journal of Economics, 109 (4): 1185-1209.

Aghion, P. and J. Tirole (1997). "Formal and Real Authority in Organizations," Journal of Political Economy 105(1): 1-29.

Anderson, E., and D. Schmittlein (1984). "Integration of the Sales Force: An Empirical Examination," RAND Journal of Economics, 15: 385-95.

Anand, B. and A. Galetovic (1998). "Weak Property Rights and Hold-Up in R\&D," mimeo, Harvard Business School.

Anton, J. and D. Yao (1994). "Expropriation and Inventions: Appropriable Rents in the Absence of Property Rights," American Economic Review 84: 190-209.

Arora, Ashish (1996). "Testing for Complementarities in Reduced Form Regressions: A Note," Economics Letters 50(1): 51-55.

Athey, S. and S. Stern (1998). “An Empirical Framework for Testing Theories About Complementarity in Organizational Design,” NBER Working Paper 6600.

Baker, G. (1992). "Incentive Contracts and Performance Measurement," Journal of Political Economy 100: 598-614.

Baker, G., R. Gibbons, and K. Murphy (1994). "Subjective Performance Measures in Optimal Incentive Contracts," Quarterly Journal of Economics 109:1125-56.

Bolton, P. and D. Scharfstein (1998). "Corporate Finance, the Theory of the Firm, and Organizations," Journal of Economic Perspectives 12(4): 95-114.

Cohen, W. and D. Levinthal (1989). "Innovation and Learning: The Two Faces of R\&D," Economic Journal, 99(397): 569-596.

Doeringer, P. and M. Piore (1971). Internal Labor Markets and Manpower Analysis. Lexington: D.C. Heath.

Gans, J. and S. Stern (1997). "Incumbency and R\&D Incentives: Licensing the Gale of Creative Destruction," mimeo, MIT.

Gibbons, R., and M. Waldman (1998). "Careers in Organizations: Theory and Evidence," Handbook of Labor Economics eds. O. Ashenfelter and D. Card, New York: North-Holland. 
Hart, O. (1995). Firms, Contracts, and Financial Structure. London: Oxford University Press.

Hauser, J. (1996). "Metrics to Value R\&D: An Annotated Bibliography," MIT ICRMOT Working Paper \#143-96.

Henderson, R. and I. Cockburn (1996). "Scale, Scope and Spillovers: The Determinants of research Productivity in Drug Discovery," Rand Journal of Economics 27(1): 32-59.

Henderson, R. and I. Cockburn (1994). "Measuring Competence? Exploring Firm Effects in Drug Discovery," Strategic Management Journal Winter Special Issue, 15: 63-84.

Holmstrom, Bengt (1982). “Moral Hazard in Teams,” Bell Journal of Economics 13: 324-40.

Holmstrom, Bengt. (1989). "Agency Costs and Innovation," Journal of Economic Behavior and Organization, 12(3): 305-27.

Holmstrom, B. and P. Milgrom (1991), "Multitask Principal-Agent Analyses: Incentive Contracts, Asset Ownership and Job Design," Journal of Law, Economics and Organization 7: 24-52.

Holmstrom, B. and P. Milgrom (1994). "The Firm as an Incentive System," American Economic Review, 84: 972-991.

Hubbard, Thomas (1998). "Why is Process Monitoring Valuable? The Use of On Board Computers in the Trucking Industry," mimeo, UCLA.

Ichniowski, C., K. Shaw, and G. Prennushi (1997). "The Effects of Human Resource Management Practices on Productivity," American Economic Review, 87(3): 291-313.

Lazear, E. (1997). “Performance Pay and Productivity,” NBER Working Paper \#5672.

Lazear, E. and S. Rosen (1981), "Rank Order Tournaments as Optimal Labor Contracts," Journal of Political Economy, 89: 841-864.

Lerner, J. and R. Merges (1998). "The Control of Technology Alliances: An Empirical Analysis of the Biotechnology Industry,” Journal of Industrial Economics 46(2): 125-156.

Merton, R. (1973). The Sociology of Science: Theoretical and Empirical Investigation, Chicago: University of Chicago Press.

Milgrom, P., and J. Roberts (1990). "Bargaining Costs, Influence Costs, and the Organization of Economic Activity," Perspectives on Positive Political Economy eds. J. Alt and K. Shepsle Cambridge: Cambridge University Press.

Nichols, N. (1994). "Scientific Management at Merck: An Interview with CFO Judy Lewent," Harvard Business Review, January-February, pp. 88-99.

Pakes, A. (1981). "Patents, R\&D and the Stock Market Rate of Return," NBER Working Paper \#786. 
Slade, Margaret (1996). "Multitask Agency and Contract Choice: An Empirical Exploration," International Economic Review, 37(2) :465-486.

Stein, J. (1997). "Internal Capital Markets and the Competition for Corporate Resources," Journal of Finance 52(2): 737-783.

Stern, S. (1998). "Does it Pay to Let Good Scientists do Good Science? Evidence from R\&D Job Offers," mimeo, MIT.

Zucker, L., M. Darby, and M. Brewer (1998). "Intellectual Human Capital and the Birth of U.S. Biotechnology Enterprises,” American Economic Review 88(1): 290-306. 
Figure 1

Distribution of Changes in Annual Research Budget

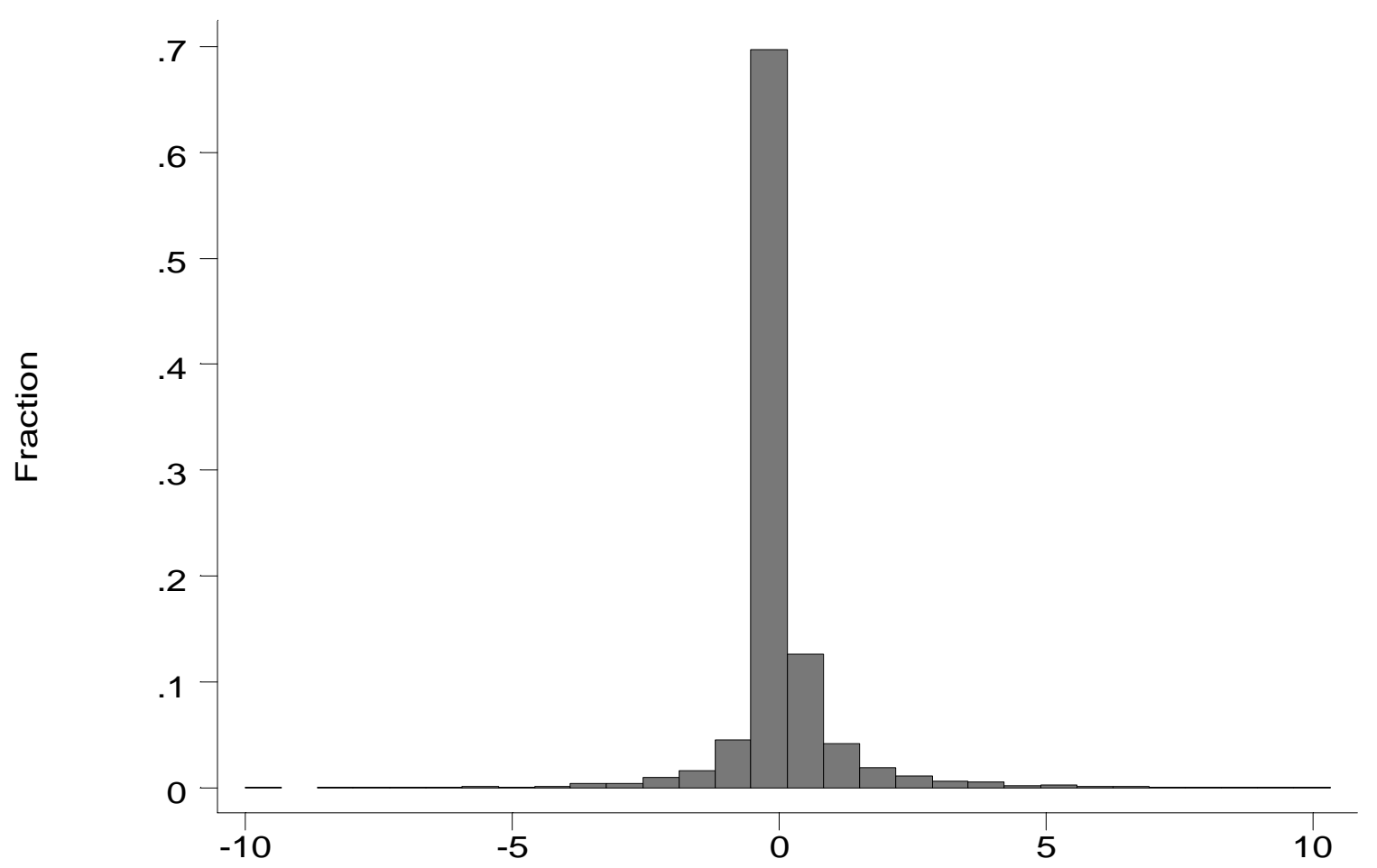

Change in Annual Research Budget 


\section{Figure 2 \\ Distribution of Patent Counts}

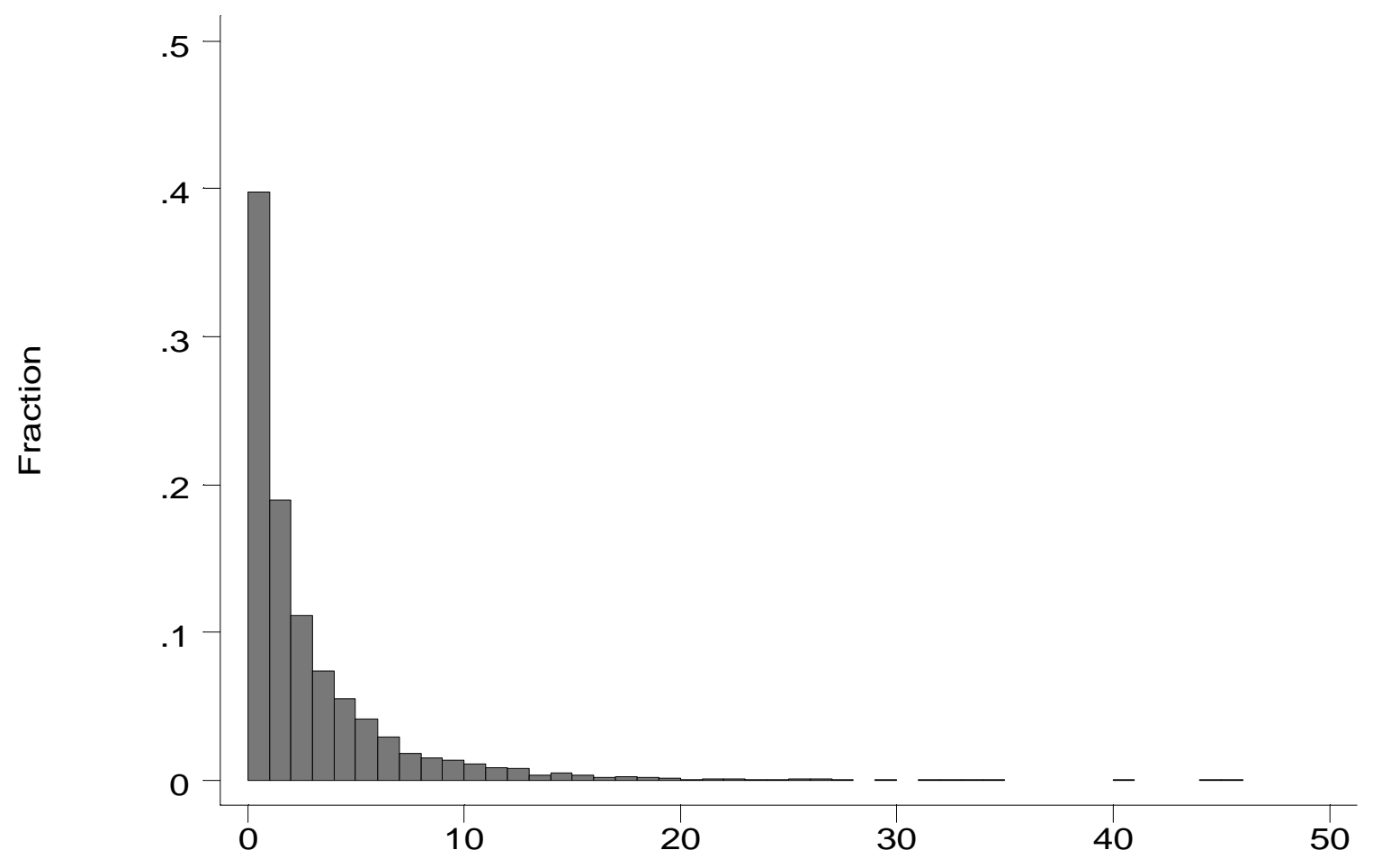

Annual Patents per Research Program 


\section{Figure 3}

\section{Distribution of Measures of Expected Patent Output}
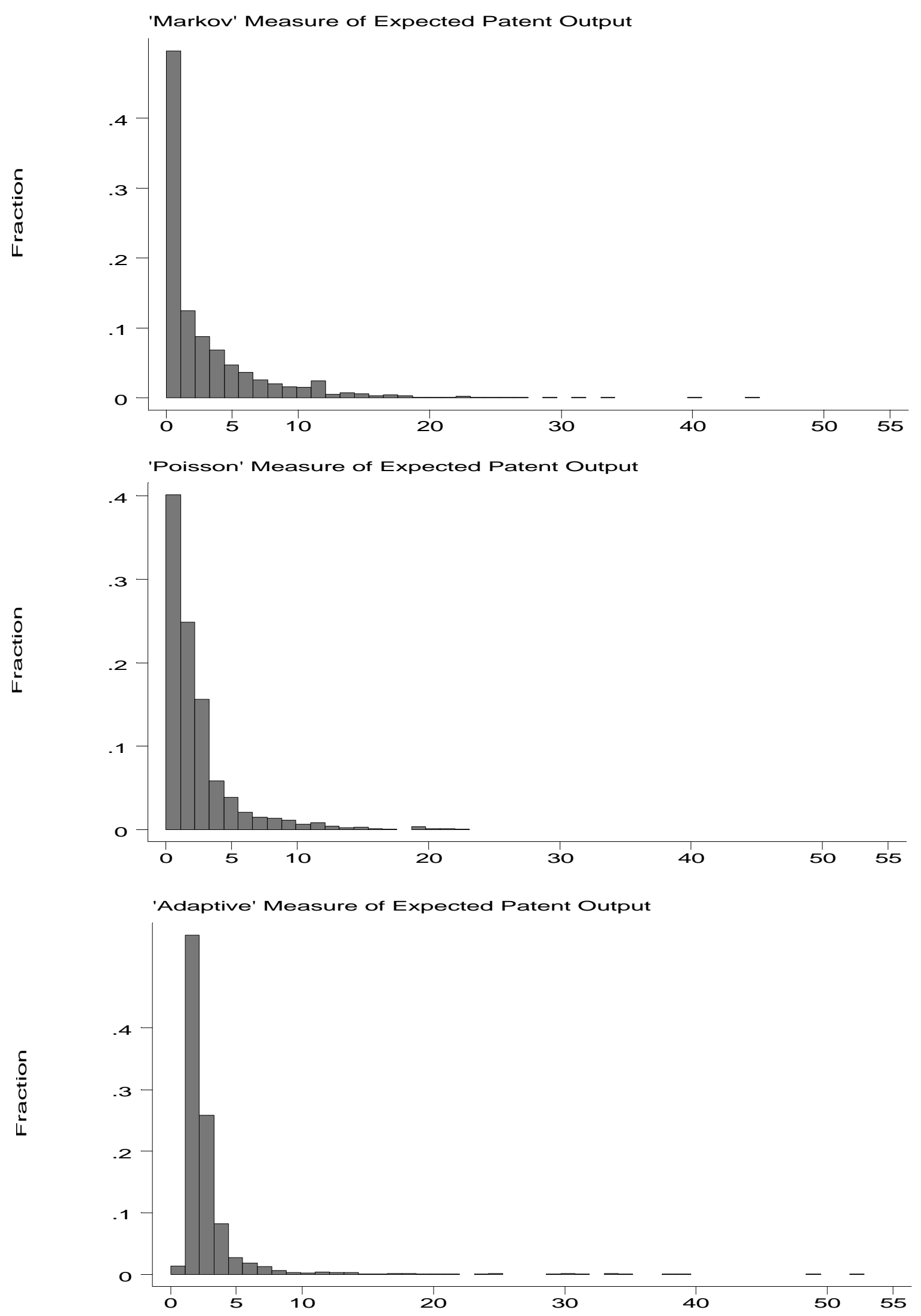


\section{Figure 4 \\ Distribution of "Adaptive" Measure of Patent Shock}

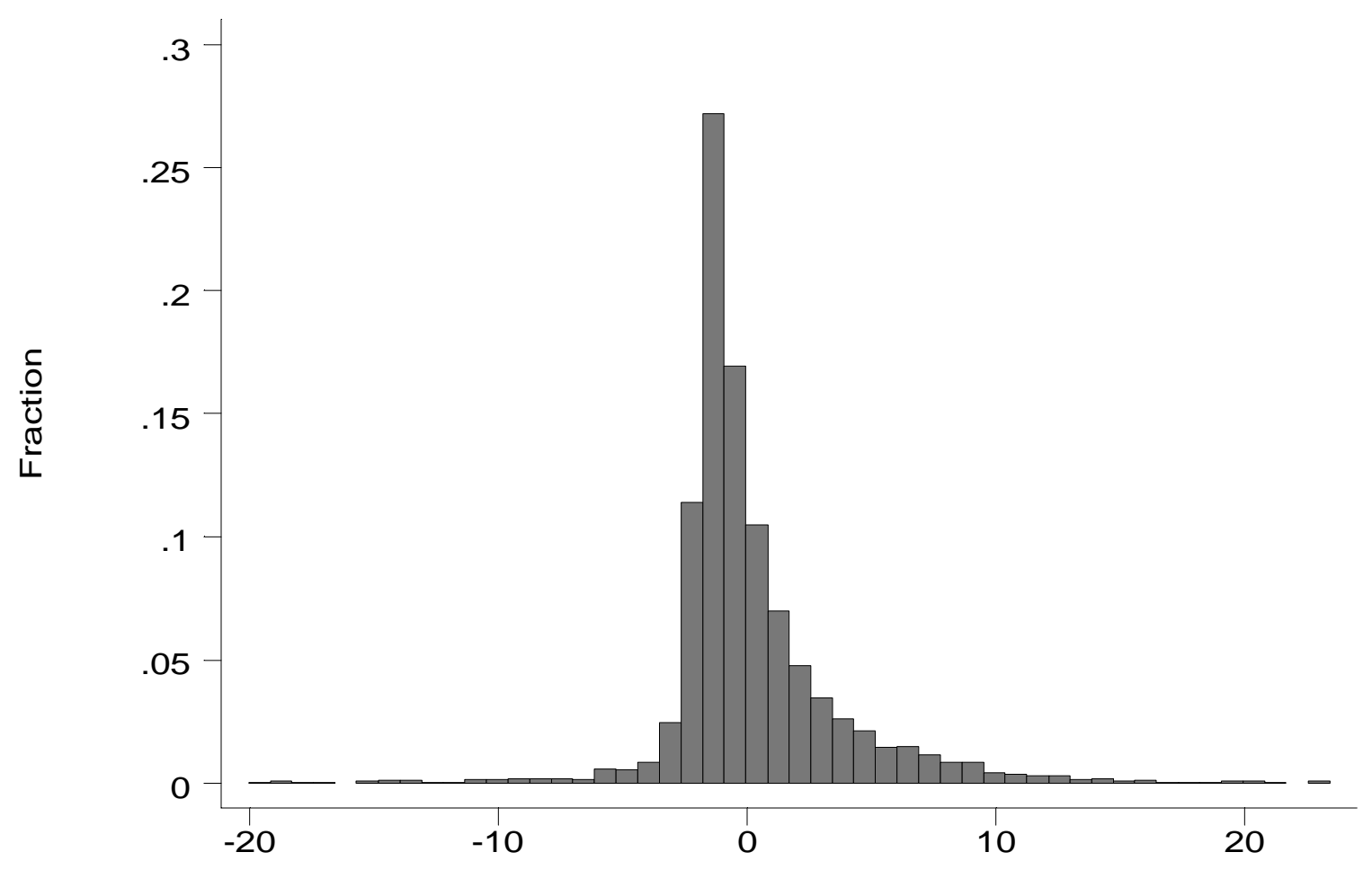

'Adaptive ' Measure of Patent Shock 


\section{TABLE 1A \\ VARIABLES AND DEFINITIONS}

\begin{tabular}{|c|c|c|}
\hline Variable Name & Definition & $\begin{array}{c}\text { Unit of } \\
\text { Observation }\end{array}$ \\
\hline \multicolumn{3}{|c|}{ FUNDING VARIABLES } \\
\hline $\mathrm{RESEARCH}_{\mathrm{j}, \mathrm{f}, \mathrm{t}}$ & $\begin{array}{l}\text { Annual expenditure on drug discovery in program } \\
\mathrm{j} \text { by firm } \mathrm{f} \text { in year } \mathrm{t} \text { in } \$ \mathrm{M} 1986 \text {, excluding clinical } \\
\text { development }\end{array}$ & program-firm-year \\
\hline$\Delta(\text { RESEARCH })_{\mathrm{i}, \mathrm{ft} \mathrm{t}}$ & RESEARCH $_{\mathrm{i} \text {.f.t }}-\mathrm{RESEARCH}_{\mathrm{ifft}, \mathrm{l}-1}$ & program-firm-year \\
\hline FIRM RESEARCH $_{\mathrm{f}, \mathrm{t}}$ & $\begin{array}{l}\text { Annual overall expenditure on drug discovery by } \\
\text { firm } \mathrm{f} \text { in year } \mathrm{t} \text { in } \$ \mathrm{M} 1986 \text {, excluding clinical } \\
\text { development }\end{array}$ & firm-year \\
\hline \multicolumn{3}{|c|}{ PATENTING VARIABLES } \\
\hline PATENTS $_{\mathrm{j}, \mathrm{f}, \mathrm{t}}$ & $\begin{array}{l}\text { Annual number of patent applications in year } t \\
\text { granted in at least two of U.S., Japan, EU; by } \\
\text { worldwide priority date }\end{array}$ & program-firm-year \\
\hline FIRM PATENTS $_{\mathrm{f}, \mathrm{t}}$ & $\begin{array}{l}\text { Annual overall number of patent applications in } \\
\text { year } t \text { granted in at least two of U.S., Japan, EU; } \\
\text { by worldwide priority date }\end{array}$ & firm-year \\
\hline
\end{tabular}




\section{TABLE 1B \\ VARIABLES AND DEFINITIONS}

\begin{tabular}{|c|c|c|}
\hline Variable Name & Definition & $\begin{array}{c}\text { Unit of } \\
\text { Observation }\end{array}$ \\
\hline \multicolumn{3}{|c|}{ ORGANIZATIONAL DESIGN VARIABLES } \\
\hline PROPUB $_{\mathrm{f}, \mathrm{t}}$ & $\begin{array}{l}\text { Likert scale variable between } 1 \text { and 5, where } \\
\text { higher values indicate that the firm promotes } \\
\text { individuals on the basis of their standing in the } \\
\text { scientific community (assigned by researcher in } \\
\text { previous project based on interviews) }\end{array}$ & firm-year \\
\hline DICTATOR $_{\mathrm{f}, \mathrm{t}}$ & $\begin{array}{l}\text { Likert scale variable between } 1 \text { and } 5 \text {, where } \\
\text { higher values indicate that the majority of the key } \\
\text { resource allocation decisions in research were } \\
\text { made by a single individual, rather than by a } \\
\text { committee of scientific peers (assigned by } \\
\text { researcher in previous project based on interviews) }\end{array}$ & firm-year \\
\hline $\begin{array}{l}\text { VICE PRESIDENT } \\
\text { TENURE }_{\mathrm{f}, \mathrm{t}}\end{array}$ & $\begin{array}{l}\text { Number of years that Vice President of Research } \\
\text { has been in position }\end{array}$ & firm-year \\
\hline \multicolumn{3}{|c|}{ MEASURES OF TECHNOLOGICAL ACTIVITY } \\
\hline Competitors' Patents $_{\mathrm{j}, \mathrm{f}, \mathrm{t}}$ & $\begin{array}{l}\text { Annual number of patent applications granted to } \\
29 \text { competitor firms }\end{array}$ & program-firm-year \\
\hline $\begin{array}{l}\text { Own Patents in Related } \\
\text { Programs } \\
\text { ifft }\end{array}$ & $\begin{array}{l}\text { Annual number of patent applications granted in } \\
\text { classes related to a given program }\end{array}$ & program-firm-year \\
\hline $\begin{array}{l}\text { Competitors' Patents in } \\
\text { Related Programs }\end{array}$ & $\begin{array}{l}\text { Annual number of patent applications granted to } \\
\text { competitors in classes related to a given program }\end{array}$ & program-firm-year \\
\hline
\end{tabular}


TABLE 2

MEANS AND STANDARD DEVIATIONS

\begin{tabular}{|c|c|c|c|}
\hline Variable & $\mathbf{N}$ & Mean & Standard Deviation \\
\hline \multicolumn{4}{|c|}{ FUNDING VARIABLES } \\
\hline Research $_{\mathrm{j}, \mathrm{ft}}$ & 2560 & 1.57 & 3.05 \\
\hline$\Delta(\text { Research })_{\mathrm{j}, \mathrm{ft}}$ & 2560 & 0.10 & 1.06 \\
\hline Firm Research ${ }_{f, t}$ & 2560 & 37.52 & 26.37 \\
\hline Scope $_{f, t}$ & 2560 & 9.88 & 4.36 \\
\hline \multicolumn{4}{|c|}{ PATENTING VARIABLES } \\
\hline Patents $_{j, f, t}$ & 2560 & 3.22 & 4.56 \\
\hline Firm Patents $\mathrm{f}_{\mathrm{f}, \mathrm{t}}$ & 2560 & 87.68 & 60.43 \\
\hline \multicolumn{4}{|c|}{ ORGANIZATIONAL DESIGN VARIABLES } \\
\hline Propub $_{\mathrm{f}, \mathrm{t}}$ & 2560 & 3.34 & 1.45 \\
\hline Dictator $_{\mathrm{f}, \mathrm{t}}$ & 2560 & 2.41 & 1.60 \\
\hline VP Tenure $_{\mathrm{f}, \mathrm{t}}$ & 2560 & 1.90 & 2.37 \\
\hline \multicolumn{4}{|c|}{ MEASURES OF TECHNOLOGICAL ACTIVITY } \\
\hline${\text { Competitors' Patents }{ }_{\mathrm{j}, \mathrm{f}, \mathrm{t}}}$ & 2560 & 54.53 & 40.54 \\
\hline $\begin{array}{l}\text { Own Patents in } \\
\text { Related Programs } \\
\text { i,f,t }\end{array}$ & 2560 & 5.80 & 7.50 \\
\hline $\begin{array}{l}\text { Competitors' Patents } \\
\text { in Related Programs } s_{\mathrm{i}, \mathrm{t}}\end{array}$ & 2560 & 114.22 & 85.16 \\
\hline
\end{tabular}


TABLE 3

ALTERNATIVE MEASURES OF

EXPECTED PATENT PRODUCTION:

\begin{tabular}{|c|c|c|c|}
\hline Expected Patent Production Measure & $\mu_{\mathrm{MARK}, \mathrm{t}}$ & $\mu_{\mathrm{POIS}, \mathrm{t}}$ & $\mu_{\mathrm{ADAP}, \mathrm{t}}$ \\
\hline Definition & $\operatorname{PATS}_{\mathrm{t}-1}$ & $\frac{\sum_{\mathrm{s}=0}^{\mathrm{t}-1} \text { PATS }_{\mathrm{s}}}{\mathrm{t}-1}$ & $\mathrm{e}^{\hat{\lambda}_{0} \mu_{\text {POII }_{t-1}}+\hat{\lambda}_{1} \ln \left(\text { DISC }_{t}\right)}$ \\
\hline Poisson Regression & $\mathrm{N}$ & $\mathrm{N}$ & $\mathrm{Y}$ \\
\hline Dependent Var & & & PATENTS \\
\hline$\mu_{\text {POIS },-1}$ & & & $\begin{array}{c}0.144 \\
(0.002)\end{array}$ \\
\hline $\operatorname{LOG}\left(\right.$ RESEARCH $\left._{\mathrm{j}, \mathrm{f},}\right)$ & & & $\begin{array}{c}0.123 \\
(\mathbf{0 . 0 0 7 )}\end{array}$ \\
\hline \multicolumn{4}{|l|}{ LOG(FIRM RESEARCH $\left.\mathrm{f}_{\mathrm{f}, \mathrm{t}}\right)$} \\
\hline \multicolumn{4}{|l|}{$\mathrm{SCOPE}_{\mathrm{f}, \mathrm{t}}$} \\
\hline \multicolumn{4}{|l|}{ YEAR $_{t}$} \\
\hline Log-Likelihood & & & -8491.77 \\
\hline Mean Expectation: & 2.42 & 1.89 & 2.60 \\
\hline Std. Deviation of Expectation & 3.88 & 2.56 & 3.18 \\
\hline
\end{tabular}




\section{TABLE 4}

\section{ALTERNATIVE PATENT OUTPUT "SHOCK” MEASURES}

\begin{tabular}{|l|c|c|}
\hline & LEVELS & $\%$ \\
\hline FORMULA & PATS $-\mu$ & $($ PATS $-\mu) / \mu$ \\
\hline MARKOV & 0.08 & 0.11 \\
\hline Mean & 2.79 & 1.30 \\
\hline Std. Dev. & \multicolumn{3}{|c|}{} \\
\hline POISSON & 0.61 & 0.63 \\
\hline Mean & 3.17 & 2.61 \\
\hline Std. Dev & \multicolumn{3}{|c|}{} \\
\hline ADAPTIVE & 0.00 & -0.07 \\
\hline Mean & 3.38 & 1.29 \\
\hline Std. Dev. &
\end{tabular}


TABLE 5

AVERAGE CHANGE IN RESEARCH FUNDING BY PATENT SHOCK \& ORGANIZATIONAL FORM

\begin{tabular}{|l|c|c|}
\hline & LO PROPUB & HI PROPUB \\
\hline "Negative" Shock & $\mathbf{- 0 . 0 1}$ & $\mathbf{0 . 0 3}$ \\
\hline "Positive" Shock & 0.18 & 0.38 \\
\hline $\begin{array}{l}\text { "Boost" in Research } \\
\text { Funding from Pos. Shock }\end{array}$ & 0.19 & 0.35 \\
\hline $\begin{array}{l}\text { Difference in "Boost" by } \\
\text { Organizational Form }\end{array}$ & \multicolumn{2}{|c|}{$.19=84 \%$} \\
\hline
\end{tabular}


TABLE 6

\section{DETERMINANTS OF CHANGES IN RESEARCH FUNDING USING ALTERNATIVE PATENT SHOCK MEASURES (\%)}

\begin{tabular}{|c|c|c|c|}
\hline \multicolumn{4}{|c|}{ DEPENDENT VARIABLE $=\Delta \mathrm{RESEARCH}$} \\
\hline & \multicolumn{3}{|c|}{ PATENT OUTPUT EXPECTATION MEASURE (\%) } \\
\hline & $\begin{array}{l}\text { MARKOV } \\
(6-1)\end{array}$ & $\begin{array}{l}\text { POISSON } \\
\quad(6-2)\end{array}$ & $\begin{array}{l}\text { ADAPTIVE } \\
(6-3)\end{array}$ \\
\hline CONSTANT & $\begin{array}{l}-1.0242 \\
(0.5811)\end{array}$ & $\begin{array}{l}-0.7800 \\
(0.4348)\end{array}$ & $\begin{array}{l}-0.8667 \\
(0.4278\end{array}$ \\
\hline \multicolumn{4}{|c|}{ INTERACTION TERMS WITH $\mathbf{X}_{\mathrm{a}}=\left(\right.$ PATENT SHOCK SH $*$ RESEARCH $\left._{\mathrm{t}-1}\right)$} \\
\hline$\alpha_{0}$ & $\begin{array}{l}-0.0050 \\
(0.0263)\end{array}$ & $\begin{array}{l}-0.0091 \\
(0.0084)\end{array}$ & $\begin{array}{l}-0.0022 \\
(0.0258)\end{array}$ \\
\hline YEAR & $\begin{array}{c}0.0024 \\
(0.0013)\end{array}$ & $\begin{array}{c}0.0001 \\
(0.0007)\end{array}$ & $\begin{array}{l}-0.0010 \\
(0.0016)\end{array}$ \\
\hline PROPUB & $\begin{array}{l}-0.0003 \\
(0.0048)\end{array}$ & $\begin{array}{c}0.0072 \\
(0.0021)\end{array}$ & $\begin{array}{r}0.0155 \\
(0.0044)\end{array}$ \\
\hline \multicolumn{4}{|l|}{ CONTROL VARIABLES } \\
\hline PROPUB & $\begin{array}{c}0.0305 \\
(0.0206)\end{array}$ & $\begin{array}{c}0.0146 \\
(0.0154)\end{array}$ & $\begin{array}{r}0.0181 \\
(0.0151)\end{array}$ \\
\hline YEAR & $\begin{array}{c}0.0131 \\
(0.0073)\end{array}$ & $\begin{array}{c}0.0104 \\
(0.0054)\end{array}$ & $\begin{array}{r}0.0114 \\
(0.0054\end{array}$ \\
\hline \multicolumn{4}{|c|}{ TECHNOLOGICAL OPPORTUNITY CONTROLS } \\
\hline Competitors' Patents Shock & $\begin{array}{c}0.0137 \\
(0.0107)\end{array}$ & $\begin{array}{c}0.0066 \\
(0.0085)\end{array}$ & $\begin{array}{r}0.0078 \\
(0.0085)\end{array}$ \\
\hline $\begin{array}{l}\text { Own Patents in Related } \\
\text { Programs Shock }\end{array}$ & $\begin{array}{l}-0.0080 \\
(0.0163)\end{array}$ & $\begin{array}{l}-0.0086 \\
(0.0121)\end{array}$ & $\begin{array}{l}-0.0113 \\
(0.0122)\end{array}$ \\
\hline $\begin{array}{l}\text { Competitors' Patents in Related } \\
\text { Programs Shock }\end{array}$ & $\begin{array}{l}-0.0437 \\
(0.0572)\end{array}$ & $\begin{array}{l}-0.0463 \\
(0.0433)\end{array}$ & $\begin{array}{l}-0.0555 \\
(0.0434)\end{array}$ \\
\hline \multicolumn{4}{|c|}{ PROGRAM SIZE AND TEMPORAL EVOLUTION CONTROLS } \\
\hline $\mathrm{RESEARCH}_{\mathrm{t}-1}$ & $\begin{array}{l}-0.0248 \\
(0.0098)\end{array}$ & $\begin{array}{c}-0.0260 \\
(0.0084)\end{array}$ & $\begin{array}{r}-\mathbf{0 . 0 2 0 0} \\
(0.0081\end{array}$ \\
\hline$\Delta \mathrm{RESEARCH}_{\mathrm{t}-1}$ & $\begin{array}{c}0.1367 \\
(0.0281)\end{array}$ & $\begin{array}{c}0.1032 \\
(0.0228)\end{array}$ & $\begin{array}{r}\mathbf{0 . 1 0 3 7} \\
(\mathbf{0 . 0 2 2 8}\end{array}$ \\
\hline R-Squared & 0.0270 & 0.0314 & 0.0336 \\
\hline \# of Observations & 1776 & 2560 & 2560 \\
\hline
\end{tabular}


TABLE 7

DETERMINANTS OF CHANGES IN RESEARCH FUNDING USING ALTERNATIVE PATENT SHOCK MEASURES (LEVELS)

\begin{tabular}{|c|c|c|c|}
\hline \multicolumn{4}{|c|}{ DEPENDENT VARIABLE $=\Delta$ RESEARCH } \\
\hline & \multicolumn{3}{|c|}{ PATENT OUTPUT EXPECTATION MEASURE (LEVELS) } \\
\hline & $\begin{array}{l}\text { MARKOV } \\
\quad(7-1)\end{array}$ & $\begin{array}{l}\text { POISSON } \\
\quad(7-2)\end{array}$ & $\begin{array}{l}\text { ADAPTIVE } \\
\quad(7-3)\end{array}$ \\
\hline CONSTANT & $\begin{array}{l}-0.8919 \\
(0.4306)\end{array}$ & $\begin{array}{l}-0.8468 \\
(0.4329)\end{array}$ & $\begin{array}{l}-0.8715 \\
(0.4289)\end{array}$ \\
\hline \multicolumn{4}{|c|}{ 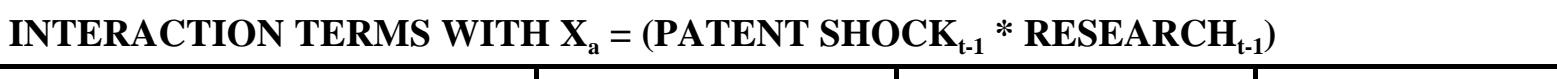 } \\
\hline$\alpha_{0}$ & $\begin{array}{l}0.0023 \\
(0.0055)\end{array}$ & $\begin{array}{l}-0.0028 \\
(0.0044)\end{array}$ & $\begin{array}{l}-0.0033 \\
(0.0047)\end{array}$ \\
\hline YEAR & $\begin{array}{c}0.0004 \\
(0.0003)\end{array}$ & $\begin{array}{c}0.0001 \\
(0.0003)\end{array}$ & $\begin{array}{l}0.0000 \\
(0.0003)\end{array}$ \\
\hline PROPUB & $\begin{array}{l}-0.0011 \\
(0.0010)\end{array}$ & $\begin{array}{c}0.0018 \\
(0.0008) \\
\end{array}$ & $\begin{array}{c}0.0028 \\
(0.0008) \\
\end{array}$ \\
\hline \multicolumn{4}{|l|}{ CONTROL VARIABLES } \\
\hline PROPUB & $\begin{array}{c}0.0240 \\
(0.0152)\end{array}$ & $\begin{array}{c}0.0190 \\
(0.0153)\end{array}$ & $\begin{array}{c}0.0217 \\
(0.0152)\end{array}$ \\
\hline YEAR & $\begin{array}{c}0.0113 \\
(0.0054)\end{array}$ & $\begin{array}{c}0.0111 \\
(0.0054)\end{array}$ & $\begin{array}{c}0.0113 \\
(0.0054)\end{array}$ \\
\hline \multicolumn{4}{|c|}{ TECHNOLOGICAL OPPORTUNITY CONTROLS } \\
\hline Competitors' Patents Shock & $\begin{array}{c}0.0092 \\
(0.0085)\end{array}$ & $\begin{array}{c}0.0083 \\
(0.0085)\end{array}$ & $\begin{array}{c}0.0081 \\
(0.0085)\end{array}$ \\
\hline $\begin{array}{l}\text { Own Patents in Related } \\
\text { Programs Shock }\end{array}$ & $\begin{array}{l}-0.0040 \\
(0.0123)\end{array}$ & $\begin{array}{l}-0.0069 \\
(0.0123)\end{array}$ & $\begin{array}{l}-0.0083 \\
(0.0122)\end{array}$ \\
\hline $\begin{array}{l}\text { Competitors' Patents in Related } \\
\text { Programs Shock }\end{array}$ & $\begin{array}{l}-0.0390 \\
(0.0436) \\
\end{array}$ & $\begin{array}{l}-0.0503 \\
(0.0437) \\
\end{array}$ & $\begin{array}{l}-0.0576 \\
(0.0436) \\
\end{array}$ \\
\hline \multicolumn{4}{|c|}{ PROGRAM SIZE AND TEMPORAL EVOLUTION CONTROLS } \\
\hline $\mathrm{RESEARCH}_{\mathrm{t}-1}$ & $\begin{array}{l}-0.0102 \\
(0.0079)\end{array}$ & $\begin{array}{l}-0.0214 \\
(0.0085)\end{array}$ & $\begin{array}{l}-0.0146 \\
(0.0081)\end{array}$ \\
\hline$\Delta$ RESEARCH $_{\mathrm{t}-1}$ & $\begin{array}{c}0.1093 \\
(0.0230)\end{array}$ & $\begin{array}{c}0.1079 \\
(0.0229)\end{array}$ & $\begin{array}{c}0.1097 \\
(0.0229)\end{array}$ \\
\hline R-Squared & 0.0179 & 0.0122 & 0.0275 \\
\hline \# of Observations & 2560 & 2560 & 2560 \\
\hline
\end{tabular}


TABLE 8

EXPLORING ROBUSTNESS TO MODEL SPECIFICATION

$($ PATENT SHOCK MEASURE = ADAPTIVE (\%))

\begin{tabular}{|c|c|c|c|}
\hline & $\mathrm{X}_{\mathrm{a}}=(\mathrm{PATENT}$ & \multicolumn{2}{|c|}{$\mathrm{X}_{\mathrm{a}}=\left(\mathrm{PATENT} \mathrm{SHOCK}_{\mathrm{t}-1}\right)$} \\
\hline & $\begin{array}{c}\text { DEPENDENT } \\
\text { VARIABLE = } \\
\text { RESEARCH }_{\mathrm{t}} \\
(8-1)\end{array}$ & $\begin{array}{c}\text { DEPENDENT } \\
\text { VARIABLE = } \\
\triangle \text { RESEARCH }_{\mathrm{t}} \\
(8-2)\end{array}$ & $\begin{array}{c}\text { DEPENDENT } \\
\text { VARIABLE = } \\
\Delta \text { RESEARCH }^{\prime} \\
\text { RESEARCH }_{\mathrm{t}-1} \\
(8-3)\end{array}$ \\
\hline CONSTANT & $\begin{array}{l}-0.8668 \\
(0.4278)\end{array}$ & $\begin{array}{l}-0.7378 \\
(0.4326)\end{array}$ & $\begin{array}{l}-64.3954 \\
(93.0276)\end{array}$ \\
\hline \multicolumn{4}{|c|}{ INTERACTION TERMS WITH $\mathrm{X}_{\mathrm{a}}$} \\
\hline$\alpha_{0}$ & $\begin{array}{l}-0.0022 \\
(0.0258)\end{array}$ & $\begin{array}{c}0.0659 \\
(0.0544)\end{array}$ & $\begin{array}{l}-20.1892 \\
(13.9308)\end{array}$ \\
\hline YEAR & $\begin{array}{l}-0.0010 \\
(0.0016)\end{array}$ & $\begin{array}{l}-0.0005 \\
(0.0042)\end{array}$ & $\begin{array}{c}1.6183 \\
(0.9941)\end{array}$ \\
\hline PROPUB & $\begin{array}{c}0.0155 \\
(0.0044)\end{array}$ & $\begin{array}{c}0.0211 \\
(0.0108)\end{array}$ & $\begin{array}{c}5.2080 \\
(2.4653)\end{array}$ \\
\hline \multicolumn{4}{|l|}{ CONTROL VARIABLES } \\
\hline PROPUB & $\begin{array}{c}0.0181 \\
(0.0151)\end{array}$ & $\begin{array}{c}0.0173 \\
(0.0153)\end{array}$ & $\begin{array}{c}0.9270 \\
(3.3708)\end{array}$ \\
\hline YEAR & $\begin{array}{c}0.0114 \\
(0.0054)\end{array}$ & $\begin{array}{c}0.0097 \\
(0.0054)\end{array}$ & $\begin{array}{c}0.9111 \\
(\mathbf{1 . 1 5 3 5 )}\end{array}$ \\
\hline \multicolumn{4}{|c|}{ TECHNOLOGICAL OPPORTUNITY CONTROLS } \\
\hline Competitors' Patents Shock & $\begin{array}{c}0.0078 \\
(0.0085)\end{array}$ & $\begin{array}{c}0.0085 \\
(0.0085)\end{array}$ & $\begin{array}{c}0.1831 \\
(1.4644)\end{array}$ \\
\hline $\begin{array}{l}\text { Own Patents in Related } \\
\text { Programs Shock }\end{array}$ & $\begin{array}{l}-0.0113 \\
(0.0122)\end{array}$ & $\begin{array}{l}-0.0095 \\
(0.0124)\end{array}$ & $\begin{array}{l}-3.7615 \\
(2.8036)\end{array}$ \\
\hline $\begin{array}{l}\text { Competitors' Patents in Related } \\
\text { Programs Shock }\end{array}$ & $\begin{array}{l}-0.0555 \\
(0.0434)\end{array}$ & $\begin{array}{l}-0.0310 \\
(0.0437)\end{array}$ & $\begin{array}{l}-6.4638 \\
(9.0078)\end{array}$ \\
\hline \multicolumn{4}{|c|}{ PROGRAM SIZE AND TEMPORAL EVOLUTION CONTROLS } \\
\hline $\mathrm{RESEARCH}_{\mathrm{t}-1}$ & $\begin{array}{c}0.9800 \\
(0.0082)\end{array}$ & $\begin{array}{l}-0.0095 \\
(0.0079)\end{array}$ & $\begin{array}{l}-1.6113 \\
(1.4736)\end{array}$ \\
\hline$\Delta$ RESEARCH $_{\mathrm{t}-1}$ & $\begin{array}{c}0.1037 \\
(0.0227)\end{array}$ & $\begin{array}{c}0.1090 \\
(0.0229)\end{array}$ & $\begin{array}{l}-0.4307 \\
(3.9502)\end{array}$ \\
\hline R-Squared & 0.8836 & 0.0212 & 0.0228 \\
\hline \# of Observations & 2560 & 2560 & 1469 \\
\hline
\end{tabular}




\section{TABLE 9}

EXTENDING MODEL TO INCLUDE AUTHORITY MEASURES $($ PATENT SHOCK MEASURE $=$ ADAPTIVE $(\%)$ )

\begin{tabular}{|c|c|c|}
\hline \multicolumn{3}{|c|}{ DEPENDENT VARIABLE $=\Delta$ RESEARCH } \\
\hline & $(9-1)$ & $(9-2)$ \\
\hline CONSTANT & $\begin{array}{l}-0.6155 \\
(0.4445)\end{array}$ & $\begin{array}{l}-0.6928 \\
(0.4597)\end{array}$ \\
\hline \multicolumn{3}{|c|}{ 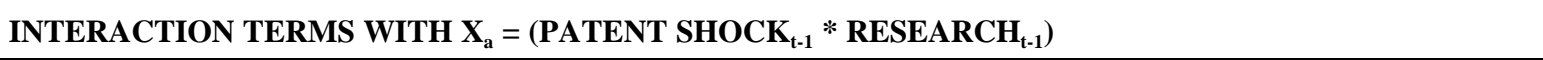 } \\
\hline$\alpha_{0}$ & $\begin{array}{l}-0.0056 \\
(0.0258)\end{array}$ & $\begin{array}{l}-0.0024 \\
(0.0263)\end{array}$ \\
\hline YEAR & $\begin{array}{l}-0.0005 \\
(0.0016)\end{array}$ & $\begin{array}{l}-0.0005 \\
(0.0016)\end{array}$ \\
\hline PROPUB & $\begin{array}{c}0.0220 \\
(\mathbf{0 . 0 0 5 8})\end{array}$ & $\begin{array}{c}0.0233 \\
(0.0061)\end{array}$ \\
\hline DICTATOR & $\begin{array}{l}-0.0092 \\
(0.0049)\end{array}$ & $\begin{array}{l}-0.0106 \\
(0.0055)\end{array}$ \\
\hline VP TENURE & & $\begin{array}{l}-0.0012 \\
(0.0019)\end{array}$ \\
\hline \multicolumn{3}{|l|}{ CONTROL VARIABLES } \\
\hline PROPUB & $\begin{array}{c}0.0060 \\
(0.0167)\end{array}$ & $\begin{array}{c}0.0100 \\
(0.0171)\end{array}$ \\
\hline DICTATOR & $\begin{array}{c}0.0288 \\
(\mathbf{0 . 0 1 5 5})\end{array}$ & $\begin{array}{c}0.0210 \\
(0.0173)\end{array}$ \\
\hline VP TENURE & & $\begin{array}{c}0.0026 \\
(0.0108)\end{array}$ \\
\hline YEAR & $\begin{array}{c}0.0080 \\
(0.0056)\end{array}$ & $\begin{array}{c}0.0092 \\
(0.0059)\end{array}$ \\
\hline \multicolumn{3}{|c|}{ TECHNOLOGICAL OPPORTUNITY CONTROLS } \\
\hline Competitors' Patents Shock & $\begin{array}{c}0.0084 \\
(0.0085) \\
\end{array}$ & $\begin{array}{r}0.0084 \\
(0.0085) \\
\end{array}$ \\
\hline Own Patents in Related Programs Shock & $\begin{array}{l}-0.0129 \\
(0.0122) \\
\end{array}$ & $\begin{array}{l}-0.0129 \\
(0.0122) \\
\end{array}$ \\
\hline Competitors' Patents in Related Programs Shock & $\begin{array}{l}-0.0435 \\
(0.0436)\end{array}$ & $\begin{array}{l}-0.0436 \\
(0.0439)\end{array}$ \\
\hline \multicolumn{3}{|c|}{ PROGRAM SIZE AND TEMPORAL EVOLUTION CONTROLS } \\
\hline $\mathrm{RESEARCH}_{\mathrm{t}-1}$ & $\begin{array}{l}-0.0209 \\
(0.0082)\end{array}$ & $\begin{array}{l}-0.0212 \\
(0.0082)\end{array}$ \\
\hline$\Delta$ RESEARCH $_{\mathrm{t}-1}$ & $\begin{array}{c}0.1029 \\
(\mathbf{0 . 0 2 2 8})\end{array}$ & $\begin{array}{c}0.1022 \\
(0.0228)\end{array}$ \\
\hline R-Squared & 0.0361 & 0.0366 \\
\hline \# of Observations & 2560 & 2560 \\
\hline
\end{tabular}


TABLE 10

EXPLORING ROBUSTNESS TO SCALE \& SCOPE SHOCK MEASURE $($ PATENT SHOCK MEASURE = SCALE \& SCOPE)

\begin{tabular}{|c|c|c|}
\hline \multicolumn{3}{|c|}{ DEPENDENT VARIABLE $=\triangle$ RESEARCH } \\
\hline & $\begin{array}{l}\text { S\&S Percent } \\
\quad(10-1)\end{array}$ & $\begin{array}{l}\text { S\&S Level } \\
\quad(10-2)\end{array}$ \\
\hline CONSTANT & $\begin{array}{l}-0.7673 \\
(0.4470)\end{array}$ & $\begin{array}{l}-0.07610 \\
(0.4460)\end{array}$ \\
\hline \multicolumn{3}{|c|}{ INTERACTION TERMS WITH $\mathbf{X}_{\mathrm{a}}=\left(\right.$ PATENT SHOCK $_{\mathrm{t}-1} *$ RESEARCH $\left._{\mathrm{t}-1}\right)$} \\
\hline$\alpha_{0}$ & $\begin{array}{c}0.0055 \\
(0.0213) \\
\end{array}$ & $\begin{array}{l}0.0010 \\
(0.0045) \\
\end{array}$ \\
\hline YEAR & $\begin{array}{c}0.0017 \\
(0.0014)\end{array}$ & $\begin{array}{c}0.0001 \\
(0.0003)\end{array}$ \\
\hline PROPUB & $\begin{array}{c}0.0094 \\
(0.0057)\end{array}$ & $\begin{array}{c}0.0033 \\
(0.0012)\end{array}$ \\
\hline DICTATOR & $\begin{array}{l}-0.0070 \\
(0.0050)\end{array}$ & $\begin{array}{l}-0.0025 \\
(0.0011)\end{array}$ \\
\hline \multicolumn{3}{|l|}{ CONTROL VARIABLES } \\
\hline PROPUB & $\begin{array}{c}0.0071 \\
(0.0168)\end{array}$ & $\begin{array}{c}0.0078 \\
(0.0167)\end{array}$ \\
\hline DICTATOR & $\begin{array}{c}\mathbf{0 . 0 3 1 2} \\
(\mathbf{0 . 0 1 5 6 )} \\
\end{array}$ & $\begin{array}{r}0.0319 \\
(0.0156) \\
\end{array}$ \\
\hline YEAR & $\begin{array}{c}\mathbf{0 . 0 0 9 7} \\
(\mathbf{0 . 0 0 5 6 )}\end{array}$ & $\begin{array}{c}0.0096 \\
(0.0056)\end{array}$ \\
\hline \multicolumn{3}{|c|}{ TECHNOLOGICAL OPPORTUNITY CONTROLS } \\
\hline Competitors' Patents Shock & $\begin{array}{c}0.0097 \\
(0.0056)\end{array}$ & $\begin{array}{l}0.0085 \\
(0.0085)\end{array}$ \\
\hline Own Patents in Related Programs Shock & $\begin{array}{l}-0.0110 \\
(0.0123)\end{array}$ & $\begin{array}{l}-0.0093 \\
(0.0123)\end{array}$ \\
\hline $\begin{array}{l}\text { Competitors' Patents in Related Programs } \\
\text { Shock }\end{array}$ & $\begin{array}{l}-0.0374 \\
(0.0438)\end{array}$ & $\begin{array}{l}-0.0380 \\
(0.0438)\end{array}$ \\
\hline \multicolumn{3}{|c|}{ PROGRAM SIZE AND TEMPORAL EVOLUTION CONTROLS } \\
\hline $\mathrm{RESEARCH}_{\mathrm{t}-1}$ & $\begin{array}{l}\mathbf{- 0 . 0 1 8 4} \\
(\mathbf{0 . 0 0 8 0 )} \\
\end{array}$ & $\begin{array}{l}-0.0155 \\
(0.0080) \\
\end{array}$ \\
\hline$\Delta$ RESEARCH $_{t-1}$ & $\begin{array}{c}0.1040 \\
(0.0228)\end{array}$ & $\begin{array}{c}0.1049 \\
(0.0229)\end{array}$ \\
\hline R-Squared & 0.0292 & 0.0289 \\
\hline \# of Observations & 2560 & 2560 \\
\hline
\end{tabular}


TABLE 11

EXPLORING ROBUSTNESS TO YEAR/FIRM/CLASS CONTROLS

$($ PATENT SHOCK MEASURE $=$ ADAPTIVE $(\%))$

\begin{tabular}{|c|c|c|c|c|}
\hline \multicolumn{5}{|c|}{$\begin{array}{c}\text { DEPENDENT VARIABLE }=\Delta \text { RESEARCH } \\
(11-1)\end{array}$} \\
\hline CONSTANT & $\begin{array}{l}-0.4772 \\
(0.4071)\end{array}$ & $\begin{array}{l}-0.1103 \\
(0.3451)\end{array}$ & $\begin{array}{l}-0.5463 \\
(0.4417)\end{array}$ & $\begin{array}{l}-0.7440 \\
(0.4440)\end{array}$ \\
\hline \multicolumn{5}{|c|}{ 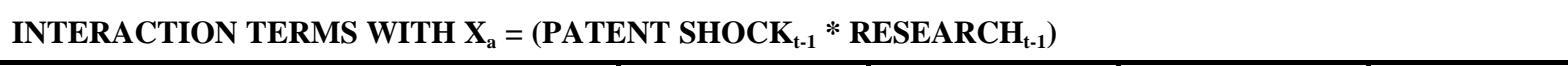 } \\
\hline$\alpha_{0}$ & $\begin{array}{l}-0.0060 \\
(0.0259)\end{array}$ & $\begin{array}{l}-0.0062 \\
(0.0261)\end{array}$ & $\begin{array}{c}0.1492 \\
(0.0506)\end{array}$ & $\begin{array}{l}-0.0103 \\
(0.0851)\end{array}$ \\
\hline YEAR & $\begin{array}{l}-0.0005 \\
(0.0016)\end{array}$ & $\begin{array}{l}-0.0005 \\
(0.0016)\end{array}$ & & $\begin{array}{c}0.0034 \\
(0.0020)\end{array}$ \\
\hline PROPUB & $\begin{array}{c}0.0222 \\
(0.0058)\end{array}$ & $\begin{array}{c}0.0216 \\
(0.0058)\end{array}$ & $\begin{array}{c}0.0352 \\
(0.0065)\end{array}$ & $\begin{array}{l}-0.0090 \\
(0.0155)\end{array}$ \\
\hline DICTATOR & $\begin{array}{l}-0.0097 \\
(0.0049)\end{array}$ & $\begin{array}{l}-\mathbf{0 . 0 0 9 0} \\
(0.0050)\end{array}$ & $\begin{array}{l}-\mathbf{0 . 0 2 2 1} \\
(0.0058)\end{array}$ & $\begin{array}{l}-0.0076 \\
(0.0099)\end{array}$ \\
\hline Year Interaction Effects & & & Significant & \\
\hline Firm Interaction Effects & & & & Insignificant \\
\hline \multicolumn{5}{|l|}{ CONTROL VARIABLES } \\
\hline PROPUB & $\begin{array}{c}0.0052 \\
(0.0165)\end{array}$ & $\begin{array}{l}-0.0027 \\
(0.0440)\end{array}$ & $\begin{array}{c}0.0007 \\
(0.0166)\end{array}$ & $\begin{array}{c}0.0073 \\
(0.0166)\end{array}$ \\
\hline DICTATOR & $\begin{array}{c}0.0269 \\
(0.0154)\end{array}$ & $\begin{array}{l}-0.0053 \\
(0.0258)\end{array}$ & $\begin{array}{c}\mathbf{0 . 0 3 4 5} \\
(\mathbf{0 . 0 1 5 5})\end{array}$ & $\begin{array}{c}0.0281 \\
(0.0156)\end{array}$ \\
\hline YEAR & $\begin{array}{c}0.0059 \\
(0.0051)\end{array}$ & & $\begin{array}{c}0.0073 \\
(0.0056)\end{array}$ & $\begin{array}{c}0.0096 \\
(0.0056)\end{array}$ \\
\hline \multicolumn{5}{|c|}{ TECHNOLOGICAL OPPORTUNITY CONTROLS } \\
\hline Competitors' Patents Shock & & $\begin{array}{c}0.0045 \\
(0.0087)\end{array}$ & $\begin{array}{c}0.0080 \\
(0.0084)\end{array}$ & $\begin{array}{c}0.0085 \\
(0.0084)\end{array}$ \\
\hline Own Patents in Related Programs Shock & & $\begin{array}{l}-\mathbf{0 . 0 1 9 3} \\
(0.0127)\end{array}$ & $\begin{array}{l}-0.0122 \\
(0.0122)\end{array}$ & $\begin{array}{l}-0.0156 \\
(0.0123)\end{array}$ \\
\hline $\begin{array}{l}\text { Competitors' Patents in Related Programs } \\
\text { Shock }\end{array}$ & & $\begin{array}{l}-0.1157 \\
(0.0582)\end{array}$ & $\begin{array}{l}-0.0567 \\
(0.0435)\end{array}$ & $\begin{array}{l}-0.0614 \\
(0.0437)\end{array}$ \\
\hline \multicolumn{5}{|c|}{ PROGRAM SIZE AND TEMPORAL EVOLUTION CONTROLS } \\
\hline $\mathrm{RESEARCH}_{\mathrm{t}-1}$ & & $\begin{array}{l}-\mathbf{0 . 0 3 5 9} \\
(0.0089)\end{array}$ & $\begin{array}{l}-0.0112 \\
(0.0083)\end{array}$ & $\begin{array}{l}-0.0242 \\
(0.0083)\end{array}$ \\
\hline$\Delta$ RESEARCH $_{\mathrm{t}-1}$ & & $\begin{array}{c}0.1043 \\
(0.0229)\end{array}$ & $\begin{array}{c}0.0948 \\
(0.0231)\end{array}$ & $\begin{array}{c}0.0957 \\
(0.0228)\end{array}$ \\
\hline Year Effects & & Significant & & \\
\hline Firm Effects & & Insignificant & & \\
\hline Class Effects & & Insignificant & & \\
\hline R-Squared & 0.0252 & 0.0515 & 0.0593 & 0.0482 \\
\hline \# of Observations & 2560 & 2560 & 2560 & 2560 \\
\hline
\end{tabular}

